\title{
Anomalous seafloor backscatter patterns in methane venting areas, Dnepr paleo-delta, NW Black Sea
}

Lieven Naudts, Jens Greinert, Yuriy Artemov, Stan E. Beaubien, Christian Borowski, Marc De Batist

\begin{abstract}
The relation between acoustic seafloor backscatter and seep distribution is examined by integrating multibeam backscatter data and seep locations detected by single-beam echosounder. This study is further supported by side scan sonar recordings, high-resolution $5 \mathrm{kHz}$ seismic data, pore-water analysis, grain-size analysis and visual seafloor observations. The datasets were acquired during the 2003 and 2004 expeditions of the EC-funded CRIMEA project in the Dnepr paleo-delta area, northwestern Black Sea.

More than 600 active methane seeps were hydro-acoustically detected within a small $(3.96 \mathrm{~km}$ by $3.72 \mathrm{~km}$ ) area on the continental shelf of the Dnepr paleo-delta in water depths ranging from $-72 \mathrm{~m}$ to $-156 \mathrm{~m}$. Multibeam and side scan sonar recordings show backscatter patterns that are clearly associated with seepage or with a present dune area. Seeps generally occur within medium- to highbackscatter areas which often coincide with pockmarks.

High-resolution seismic data reveal the presence of an undulating gas front, i.e. the top of the free gas in the subsurface, which domes up towards and intersects the seafloor at locations where gas seeps and medium- to high-backscatter values are detected. Pore-water analysis of 4 multi-cores, taken at different backscatter intensity sites, shows a clear correlation between backscatter intensity and dissolved methane fluxes. All analyzed chemical species indicate increasing anaerobic oxidation of methane (AOM) from medium- to high-backscatter locations. This is confirmed by visual seafloor observations, showing bacterial mats and authigenic carbonates formed by AOM. Grain-size analysis of the 4 multi-cores only reveals negligible variations between the different backscatter sites.

Integration of all datasets leads to the conclusion that the observed backscatter patterns are the result of ongoing methane seepage and the precipitation of methane-derived authigenic carbonates (MDACs) caused by AOM. The carbonate formation also appears to lead to a gradual (self-)sealing of the seeps by cementing fluid pathways/horizons followed by a relocation of the bubble-releasing locations.
\end{abstract}

\section{Keywords}

Methane seeps; acoustic seafloor backscatter; anaerobic oxidation of methane; bacterial mats; pockmarks; methane-derived authigenic carbonates 


\subsection{Introduction}

In recent years, considerable research efforts have been invested to gain a better understanding of how methane emissions from natural marine gas seeps contribute to the global atmospheric methane budget (Hovland et al., 1993; Hornafius et al., 1999; Dimitrov, 2002; Etiope and Klusman, 2002; Etiope, 2004; Judd, 2004; Kvenvolden and Rogers, 2005; Luyendyk et al., 2005). Given that methane is a potent greenhouse gas, with 21-23 times the global warming potential as the same mass of carbon dioxide (Lelieveld et al., 1998; IPCC, 2001b), a correct assessment of all natural sources is essential to better evaluate the human impact on global atmospheric methane concentrations and consequently on global climate change (IPCC, 2001a).

The amount of methane released by natural gas seeps from the seafloor, into the water column and possibly into the atmosphere, is highly variable and remains -despite several attempts at quantification- largely unknown, even for small well-studied areas (Hovland et al., 1993; Hornafius et al., 1999; Dimitrov, 2002; Etiope and Klusman, 2002; Etiope, 2004; Judd, 2004; Kvenvolden and Rogers, 2005; Luyendyk et al., 2005; Bange, 2006; Kessler et al., 2006). Current estimates of global methane fluxes from the seabed to the atmosphere vary between 0.4 and $48 \mathrm{Tg} \mathrm{yr}^{-1}$ (Judd, 2004), i.e. over two orders of magnitude. The main problems in establishing reliable estimates of regional and global fluxes are the uncertainties regarding i) the total area involved in active seepage, and ii) the temporal variability in seep intensity and activity.

Recent studies have shown that methane transfer from marine and lacustrine seeps to the atmosphere is only effective when methane is transported by bubbles released in relatively shallow water ( $<100 \mathrm{~m}$ water depth) (Leifer and Patro, 2002; MacDonald et al., 2002; Schmale et al., 2005; McGinnis et al., 2006). In most cases, even if a bubble reaches the surface with a significant size, most of the methane is dissolved into the water column and replaced by other stripped gases, particularly oxygen (in oxic conditions) and nitrogen. Therefore, only a massive release of large amounts of bubbles may create a bubble plume and enable significant volumes of methane to be transferred to the atmosphere from deeperwater seeps (> $100 \mathrm{~m}$ water depth) (Judd, 2004; McGinnis et al., 2006; Judd and Hovland, 2007).

The increased scientific interest in marine gas seeps goes hand in hand with the discovery of new seep sites around the world. The identification and delineation of seep sites on the ocean floor often arises from the detection of anomalously high acoustic backscatter on side scan sonar or multibeam echosounder recordings (Hovland, 1991; Hovland, 1992; Orange et al., 2002; Van Rensbergen et al., 2002; Johnson et al., 2003; Sager et al., 2003; Shoji et al., 2005; Gay et al., 2006; Klaucke et al., 2006; Rollet et al., 2006). High-acoustic backscatter is caused by the enhanced acoustic impedance or roughness contrast between certain regions of the seafloor and their surroundings (Blondel and Murton, 1997). At methane seeps, this contrast is primarily caused by the presence of methane-derived authigenic carbonates (MDACs), chemosynthetic "cold seep" communities (clams, tube worms), bubbles or gas hydrates in the sediment (Hovland et al., 1985; Ritger et al., 1987; Paull et al., 1992; von Rad et al., 1996; Greinert et al., 2001; Peckmann et al., 2001; Fonseca et al., 2002; Greinert et al., 2002b; Orange et al., 2002; Johnson et al., 2003; Niemann et al., 2005; Holland et al., 2006; Ivanov et al., 2007). Multibeam and side scan sonar surveys also detect changes in the seafloor morphology, which can mark the location of gas seeps (e.g. pockmarks, mud volcanoes) (Judd and Hovland, 1992; Judd and Hovland, 2007). Furthermore, seeps can be inferred from shallow seismic signatures indicative of free gas in the subsurface (e.g. shallow gas fronts, enhanced reflections, acoustic blanking) or potential gas or fluid conduits (e.g. faults, diapirs) (Judd and Hovland, 1992; Orange and Breen, 1992; Yun et al., 1999; Garcia-Gil et al., 2002; Van Rensbergen et al., 2002; Krastel et al., 2003; Naudts et al., 2006; Judd and Hovland, 2007). Direct localization of seeps, i.e. locations of bubble release, is performed by echosounders that detect gas bubbles in the water column due to the acoustic impedance contrast between water and the free gas in the bubbles (Egorov et al., 1998; Artemov, 2006; Naudts et al., 2006; Rollet 
et al., 2006).

In this paper, we examine the cause of anomalously high acoustic backscatter and its relation -in space and time, and through which processes- with gas venting on the shelf of the Dnepr paleo-delta, NW Black Sea. We use multibeam backscatter and bathymetry data, as well as side scan sonar images, very-highresolution seismic data, sediment cores, visual observations and single-beam seep detection. Our data and results confirm that acoustic seafloor backscatter analysis can be used as a proxy for seep distribution and seep activity (Greinert et al., 2010).

\subsection{Study area}

The paleo-delta of the Dnepr River is located on the outer shelf and upper continental slope of the northwestern Black Sea, west of the Crimea Peninsula (Fig. 4.1.A.). The region is wellknown for abundant gas seeps, carbonate buildups and shallow gas (Polikarpov et al., 1989; Polikarpov et al., 1992; Egorov et al., 1998; Luth et al., 1999; Peckmann et al., 2001; Thiel et al., 2001; Amouroux et al., 2002; Michaelis et al., 2002; Kruglyakova et al., 2004; Kutas et al., 2004; Popescu et al., 2004; Pape et al., 2005; Pimenov and Ivanova, 2005; Reitner et al., 2005; Schmale et al., 2005; Treude et al., 2005; McGinnis et al., 2006; Naudts et al., 2006). During the $58^{\text {th }}$ (May-June 2003) and $60^{\text {th }}$ (MayJune 2004) cruise of R.V. Vodyanitskiy, conducted during the EC (European Community)-funded CRIMEA project, almost 3000 active seeps (i.e. bubble-releasing locations) were detected with an EK-500 splitbeam echosounder within the $1540 \mathrm{~km}^{2}$ of the studied area (Fig. 4.1.A.) (Naudts et al., 2006). The distribution of these seeps is not random, but is controlled by morphology, by underlying stratigraphy and sediment properties, and by the presence of gas hydrates acting as a seal and preventing upward migrating gas to be released as bubbles in the water column (Naudts et al., 2006).

This study focuses on a small ( $3.96 \mathrm{~km}$ by 3.72 $\mathrm{km}$ ) part of the continental shelf, centered on a dense seep and pockmark site at $-92 \mathrm{~m}$ water depth (Figs. 4.1.B. and 4.1.C.). The area is characterized by a slightly undulating seafloor that dips gently at $0.55^{\circ}$ to the SE until it intersects the shelf break at $-105 \mathrm{~m}$ water depth. Within this area, 605 actively bubbling methane seeps were detected in water depths ranging from $-72 \mathrm{~m}$ to $-156 \mathrm{~m}$ (Fig. 4.1.B.). The seeps commonly occur in association with up to $3 \mathrm{~m}$ deep, large, elongated pockmarks, which are up to $100 \mathrm{~m}$ wide and $500 \mathrm{~m}$ long (Fig. 4.1.C.) (Naudts et al., 2006). These elongated pockmarks and related seep sites show a preferential NW-SE orientation, as their location is controlled by underlying, filled channels incised in the outer shelf (Naudts et al., 2006). Apart from the pockmarks, the shelf morphology is characterized by the presence of sediment dunes. These have a maximum height of $2.5 \mathrm{~m}$ and a maximum wave length of $120 \mathrm{~m}$ (Fig. 4.1.B.). The observed seeps and dunes appear to be unrelated (Naudts et al., 2006).

Only a small part of the study area lies within the oxygen-rich euphotic zone (above $-80 \mathrm{~m}$, in this part of the Black Sea). Most of it falls within the oxycline, between $-80 \mathrm{~m}$ and $-115 \mathrm{~m}$, in which the oxygen concentration decreases from 285 to $10 \mu \mathrm{M}$ at the top of the suboxic layer (Oguz, 2002). Oxygen concentration drops to zero at around $-145 \mathrm{~m}$.

Sea-air methane flux calculations show that methane emission from the study area (i.e., $\left.0.96-2.32 \mathrm{nmol} \mathrm{m}^{-2} \mathrm{~s}^{-1}\right)$ is 3 times higher than from the surrounding shelf $\left(0.32-0.77 \mathrm{nmol} \mathrm{m}^{-2}\right.$ $\left.\mathrm{s}^{-1}\right)$ and 5 times higher than from open water in the Black Sea $\left(0.19-0.47 \mathrm{nmol} \mathrm{m}^{-2} \mathrm{~s}^{-1}\right.$ ) (Schmale et al., 2005). During dives with the submersible JAGO in October 2004 (as part of the EC-funded METROL project) gas bubbles at $-92 \mathrm{~m}$ seep site were collected directly at the seafloor. The initial gas composition of the bubbles was almost pure methane ( 80 to $90 \%$ ) of presumed microbial origin as indicated by the isotopic composition (-62 to $-68{ }^{13} \mathrm{C} \%$ PDB) (McGinnis et al., 2006). Peckmann et al. (2001) assumes that the methane originates from organic-rich lacustrine sediments deposited during the Black Sea's fresh-water phase. 

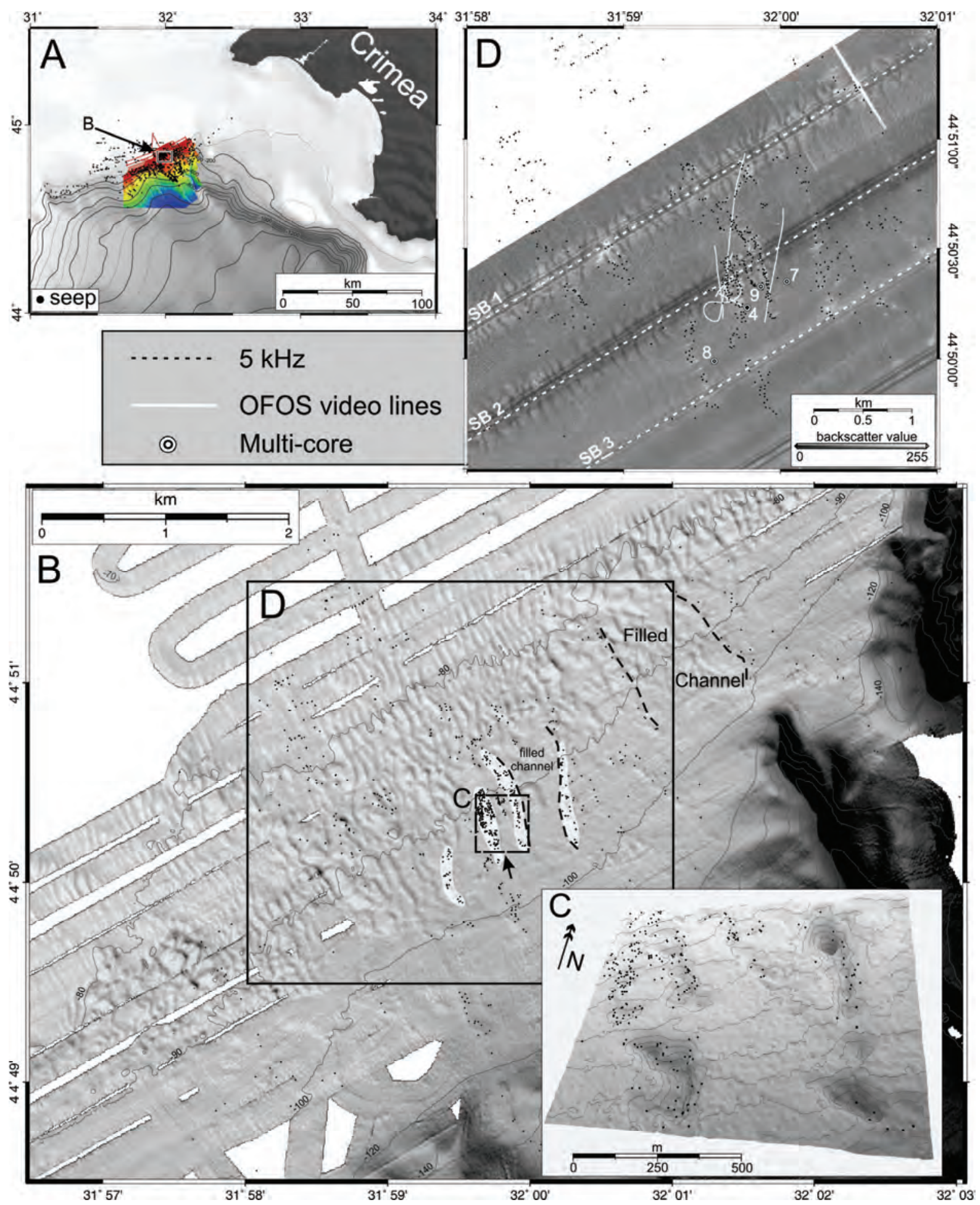

Figure 4.1. A. The location of the study area in the NW Black Sea with seeps (black dots) and acquired multibeam data (Egorov et al., 1998; Naudts et al., 2006). B. The multibeam bathymetry of the shelf with dunes, pockmarks (transparent white masks) and seeps (see Fig. 4.1.A. for location). C. Oblique view on the multibeam bathymetry of the high-intensity seep and pockmark site at $-92 \mathrm{~m}$ water depth (after Naudts et al., 2006) (see Fig. 4.1.B. for location). D. Side scan sonar mosaic of the studied area with indication for the multicores (MC: 4, 7, 8, 9), $5 \mathrm{kHz}$ seismic lines (SB 1-3: dashed white lines) and video lines (white lines) and seeps (see Fig. 4.1.B. for location). 


\subsection{Methods and data}

\subsubsection{Single-beam echosounding and seep detection}

Single-beam seep detection was performed with a hull-mounted SIMRAD EK-500 dualfrequency (38 and $120 \mathrm{kHz}$ ) split-beam echosounder installed onboard of the R.V. Professor Vodyanitskiy. This system operates with a total beam width of $7^{\circ}$. The hydroacoustic water-column data was continuously digitally recorded during both cruises and was afterwards processed with the WaveLens software package (Artemov, 2006; Artemov et al., 2007). This software traces and locates the origin of bubble streams at the seafloor based on the real target strength analysis. During the two cruises, a total length of $5261 \mathrm{~km}$ echosounder tracks was recorded within the $1540 \mathrm{~km}^{2}$ study area which resulted in the detection of 2778 active seep positions (Naudts et al., 2006). For this study we only focus on a small area on the shelf where 605 active seeps were detected based on $767 \mathrm{~km}$ of echosounder tracks (Fig. 4.1.A.-D.).

\subsubsection{Multibeam mapping}

Bathymetric and acoustic backscatter mapping was performed with a mobile $50 \mathrm{kHz}$ SeaBeam 1050 multibeam echosounder, simultaneously with the single-beam seep detection. The multibeam system was operated with $120^{\circ}$ swath, transmitting and receiving 108 beams of $3^{\circ}$ by $3^{\circ}$ beam angle. Sound-velocity profiles were acquired via CTD casts and the sound velocity at the transducers was continuously measured by an online sound-velocity probe. Data acquisition was managed with Hydrostar Online and data-processing was carried out with HDPEdit and HDPPost software from L-3 ELAC Nautik GMBH. Fine editing of the data, by deleting bad data points, was done with Fledermaus (6.1.2) software. During the two cruises, an area of $1540 \mathrm{~km}^{2}$ was covered in water depths from -57 to $-1248 \mathrm{~m}$ (Fig. 4.1.A.). In this study we focused on an area of $14.7 \mathrm{~km}^{2}$ in water depths ranging from -72 to $-156 \mathrm{~m}$ (Fig. 4.2.A.).

Raw backscatter data (bottom-amplitude values) were corrected with HDPPost for their grazing-angle dependency assuming a flat seafloor. Data were exported as gridded $x y z$ data from HDPPost and spikes were removed with Fledermaus. During processing in HDPPost, backscatter values were normalized and thus do not represent 'real' $d B$ values, but rather undefined backscatter units (BU). All maps shown in this paper are based on grids of 5 by 5 $\mathrm{m}$ cell size, except for Fig. 4.1.A.

\subsubsection{Side scan sonar imaging and subbottom profiling}

During the 2003 cruise seafloor backscatter data was also acquired with a deep-towed SONIC-3 sonar system. This system consists of a tow-fish, including a $30 \mathrm{kHz}$ side scan sonar and $5 \mathrm{kHz}$ subbottom profiler. The fish was towed 50 to $60 \mathrm{~m}$ above the seafloor resulting in 700 to $850 \mathrm{~m}$ wide swath. The theoretical maximum resolution of the acquired sonar image is $0.5 \mathrm{~m}$. Towing speed averaged 5.6 knots and the data were gridded to a pixel size of $6.4 \mathrm{~m}$, using SONIC's in-house developed processing software. 22 parallel profiles were collected with a total length of $589 \mathrm{~km}$, in total covering an area of $418 \mathrm{~km}^{2}$. Only 4 profiles are used here, covering an area of $11.8 \mathrm{~km}^{2}$ (Fig. 4.1.D.).

Very-high-resolution seismic data was acquired with the $5 \mathrm{kHz}$ profiler system. The theoretical vertical resolution is $30 \mathrm{~cm}$ and the maximum penetration is $35 \mathrm{~ms}$ two-way travel time (TWTT). Here, 3 profiles are displayed with a total length of $12.6 \mathrm{~km}$ (Fig. 4.1.D.). No processing has been carried out on the seismic data. Interpretation was carried out with the Kingdom Suite Software package.

\subsubsection{Pore-water and grain-size analysis}

Sediment coring was undertaken with a TVguided multi-core system allowing real-time selection of the coring site via the 


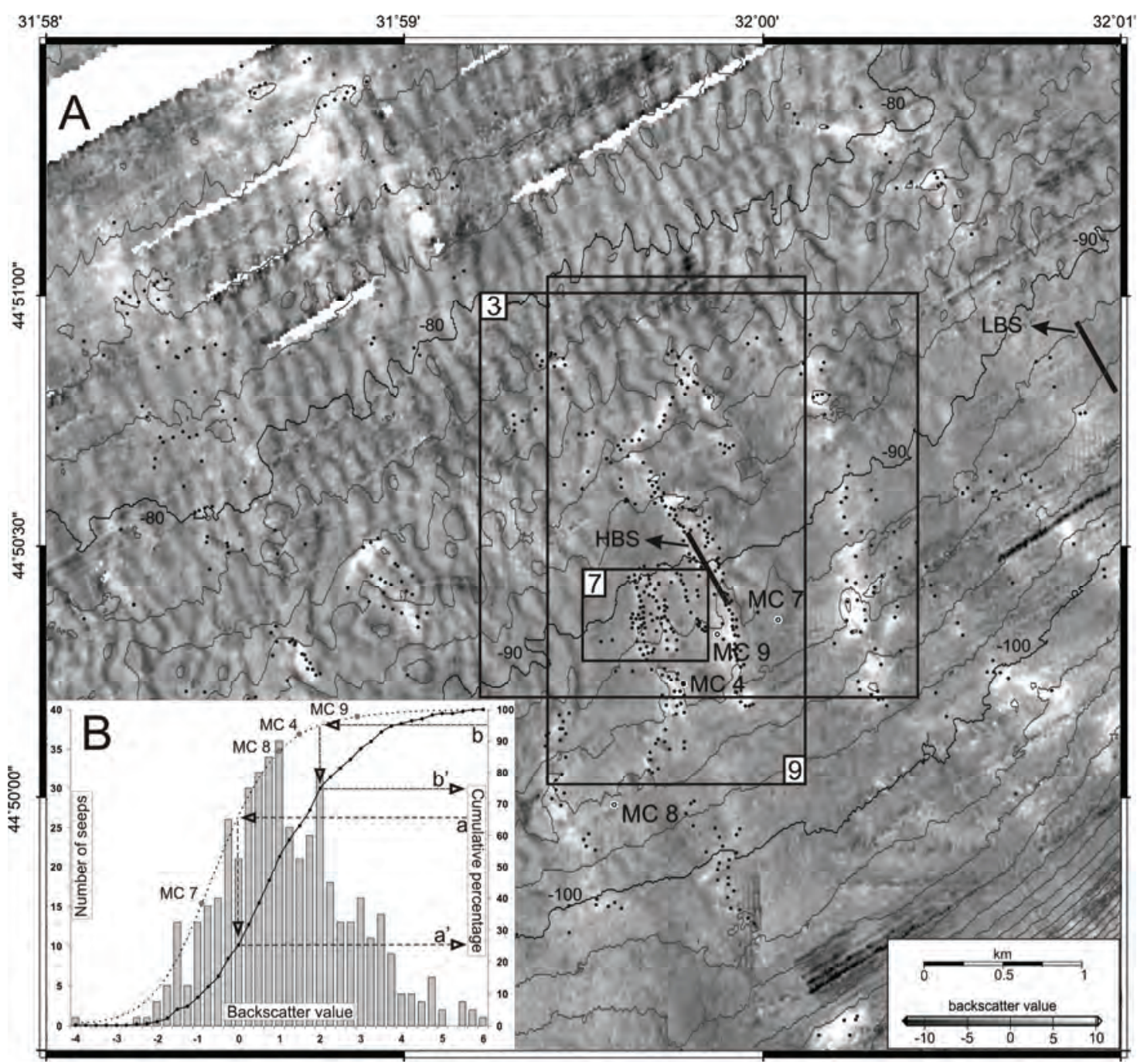

Figure 4.2. A. Multibeam-derived backscatter map overlain with bathymetric contours, detected seep locations (black dots), positions of multi-core stations and outlines for Figs. 4.3., 4.7. and 4.9. (see Fig. 4.1.B. for location). Furthermore the positions of the high-backscatter (HBS) and low-backscatter (LBS) swaths used in Figure 4.10. are indicated by the solid bold lines. B. Graph showing the distribution of the number of seeps with respect to their backscatter values, both, as a histogram and cumulative percentage curve (full line). The second cumulative percentage curve (dashed line) shows the distribution of all backscatter values recorded in the shown study area. Arrows a-a' show that $74 \%$ of all seeps occur in the high-backscatter areas above 0 BU, thus within only $33 \%$ of the studied area. Arrows b-b' show that $75 \%$ of all seeps with the lowest backscatter values occur below $2 \mathrm{BU}$.

video connection. The multi-corer accommodates 4 plastic liners with a diameter of $10 \mathrm{~cm}$ which are able to sample sediment layers up to ca. $40 \mathrm{~cm}$. Three sediment cores were taken from areas with different backscatter intensities (MC7, MC8 and MC9) and one directly at an actively bubbling bacterial mat (MC4) (Figs. 4.1.D. and 4.2.A.). Pore water was immediately extracted from the cores at a $0.5 \mathrm{~cm}$ interval with cut-off $5 \mathrm{ml}$ plastic syringes and analyzed on board for total alkalinity, hydrogen sulfide, and ammonia, following the methods of Grasshoff et al. (1999). Methane content was determined with the headspace method, following the procedure used by ODP (Pimmel and Claypool, 2001). $5 \mathrm{ml}$ of sediment were filled in $20 \mathrm{ml}$ headspace vials and heated in an oven at $70^{\circ} \mathrm{C}$ over 30 minutes. The headspace was analyzed as volume ppm and the final concentrations in $\mathrm{mol} / \mathrm{l}$ pore water were 
calculated by weighing the water content and by converting to volume percent, using $2.5 \mathrm{~g} / \mathrm{cm}^{3}$ as an assumed sediment-grain density. On-shore ion chromatography analyses were used to measure sulfate concentrations; $\mathrm{Ca}$ was analyzed by ICP-OES.

After extraction of the pore waters, five sediment samples representing each centimeter of the uppermost $5 \mathrm{~cm}$ of each core were used for grain-size analysis. Samples were sieved wet on a $50 \mu \mathrm{m}$ sieve and dried. The dried coarse fractions were dry sieved on $600,500,425,355$, $300,250,180,150,125,106$ and $90 \mu \mathrm{m}$ sieves. Since the sediment samples were rich in shells and shell debris, carbonate and organic matter were not chemically removed, to ensure that their possible contribution to generating backscatter was not omitted.

\subsubsection{Visual seafloor observations}

Visual seafloor observations were carried out with the OFOS (Ocean Floor Observation System) video sled and with the submersible JAGO to get a better insight on the distribution of possible seep-related seafloor features (e.g. seeps, bacterial mats, etc.).

OFOS carries a downward-looking online black/white video camera, two Xenon lights, a color still camera with flash, a stand-alone memory CTD and an extra color digital camera. The system was towed at about $2 \mathrm{~m}$ above the seafloor. No underwater positioning system was used with OFOS; instead the position was calculated relative to the ship's GPS antenna by taking cable length, course and ship speed into account, resulting in a maximum offset of $50 \mathrm{~m}$. Corrections for the offset between OFOS and the ship's GPS position were made for every video line separately (Fig. 4.1.D.). The made offsets were confirmed by comparing the seep distribution visible on video footage and the seeps traced by single-beam detection.

One dive with the submersible JAGO (JAGO 852) enabled us to perform additional direct seafloor observations in the area previously surveyed with OFOS. This dive took place in October 2004 as part of the R.V. Poseidon 317/3 cruise, which was conducted in the framework of the EC-funded METROL project. Video recording was done using a digital camera from inside the submersible through the large front porthole. The area covered by JAGO is shown as outline 7 in Figure 4.2. During the JAGO dive ultra-short-base-line underwater positioning was used.

\subsection{Observations and results}

\subsubsection{Backscatter anomalies, seafloor morphology and seep distribution}

The multibeam-derived seafloor backscatter map reveals three distinct features (Fig. 4.2.A.): a wave-like pattern, irregular patches with highbackscatter and acquisition artifacts with lowbackscatter values.

Based on the number of backscatter values, three backscatter classes with equal number of backscatter values were created: areas with low-backscatter (LBS: BU < -1.06), areas with medium-backscatter (MBS: $-1.06<\mathrm{BU}<0$ ) and areas with high-backscatter (HBS: BU $>0$ ) (Fig. 4.2.B.). Since each backscatter value corresponds to a grid cell, a surface of $25 \mathrm{~m}^{2}$, each backscatter class also corresponds to one third of the studied surface. Areas with the lowest $5 \%$ of backscatter values are regarded as very-low-backscatter areas (BU < -2.5). Areas with the highest $5 \%$ of backscatter values are regarded as very-high-backscatter areas (VHBS: $\mathrm{BU}>2$ ).

The wave-like pattern consists of low- to highbackscatter values that vary between -2.4 and 1.9 BU and corresponds to the field of sediment dunes (Fig. 4.1.B.), which generally display the higher backscatter values on their ENEorientated flanks (Fig. 4.3.). There is no obvious correlation between seep distribution and the backscatter pattern related to the sediment dunes.

When comparing the cumulative percentage curve of the backscatter values of the entire area (dashed line Fig. 4.2.B.) with the percentage curve and histogram of the amount of seeps falling in specific backscatter value ranges (full line Fig. 4.2B), it can be noticed that $74 \%$ of all seeps occur in the high-backscatter 


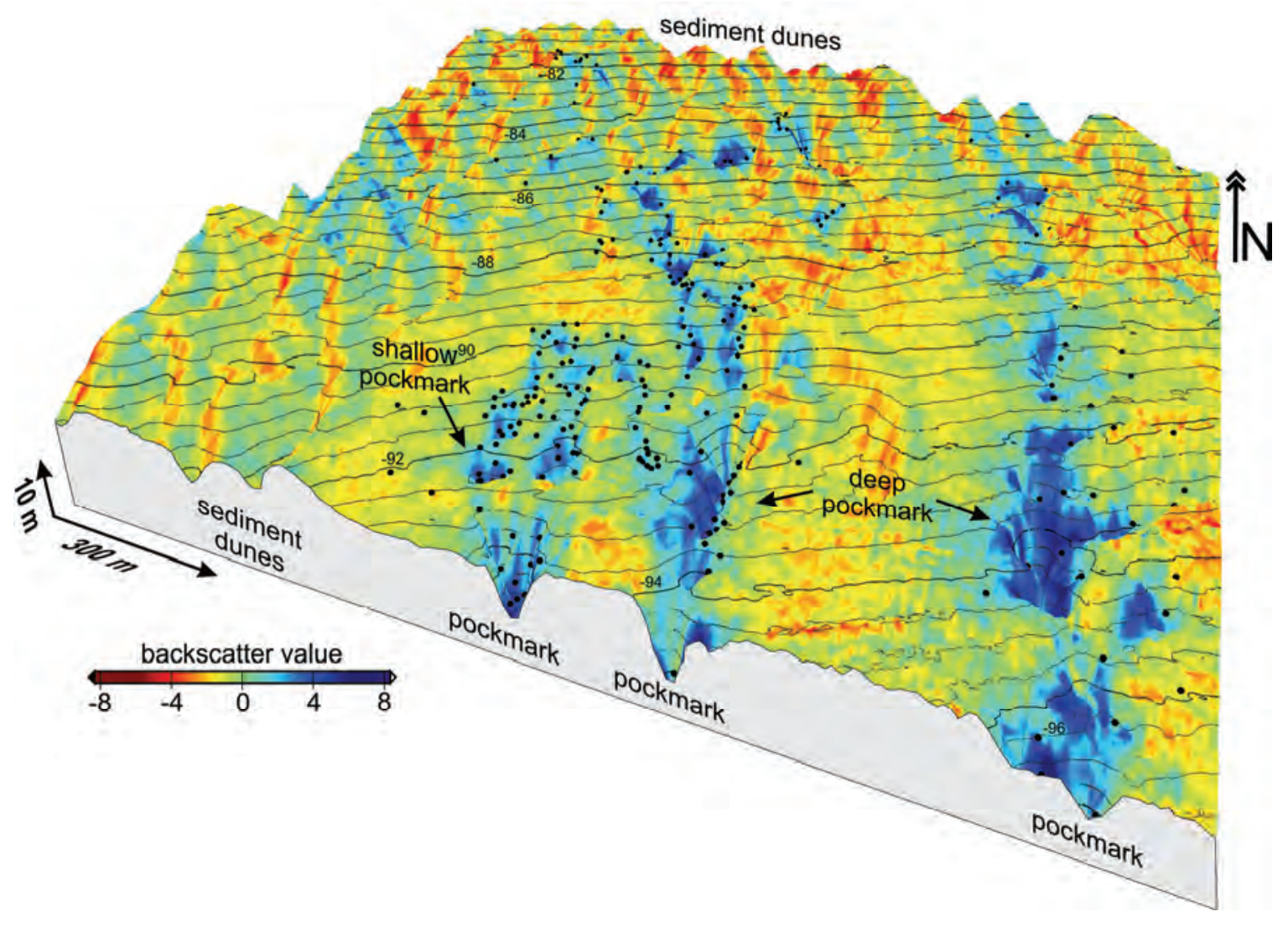

Figure 4.3. 3D view of the multibeam bathymetry overlain with the color-coded backscatter data, bathymetric contours and seep locations (black dots) (for location, see Fig. 4.2.A.). Pockmarks are characterized by high- to very-high-backscatter values with seeps located on their margins. The sediment dunes have higher backscatter values on the ENE flanks.

areas above $0 \mathrm{BU}$, thus within only $33 \%$ of the studied area (Fig. 4.2.B. a-a'). However $75 \%$ of all seeps, with the lowest backscatter values, occur below $2 \mathrm{BU}$ (Fig. 4.2.B. b-b'). This indicates that most seeps don't occur in the very-highbackscatter areas.

The pockmarks are characterized by a specific backscatter pattern (Fig. 4.3.); deeper pockmarks are characterized by higher backscatter values and lower seep densities, whereas shallower pockmarks have relatively lower backscatter values and often show much higher seep densities.

The same relations between backscatter intensity, morphology and seep locations are observed in the side scan sonar data (Figs. 4.1.D. and 4.4.).

\subsubsection{Seismic observations}

The seismic data show the presence of a distinct "gas front", which marks the top of the free gas zone in the sediments (Figs. 4.4.C., 4.4.F. and 4.4.I.) (Naudts et al., 2006; Judd and Hovland, 2007). The gas front is expressed as a high-amplitude reflection that cross-cuts the normal stratigraphy and completely masks all reflections below (Figs. 4.4.C., 4.4.F. and 4.4.I.). Naudts et al. (2006) already observed that the depth of the gas front in the study area is strongly variable and controlled by the presence of filled channels, and that seeps preferentially occur where the gas front approaches the seafloor within $10 \mathrm{~m}$ (Figs. 4.4.C., 4.4.F. and 4.4.I.). At the same time a correlation exists between the depth of the gas front and the acoustic seafloor backscatter (Fig. 4.4.). Shallow gas fronts correspond to high- and mediumbackscatter areas with seeps, whereas deep gas 

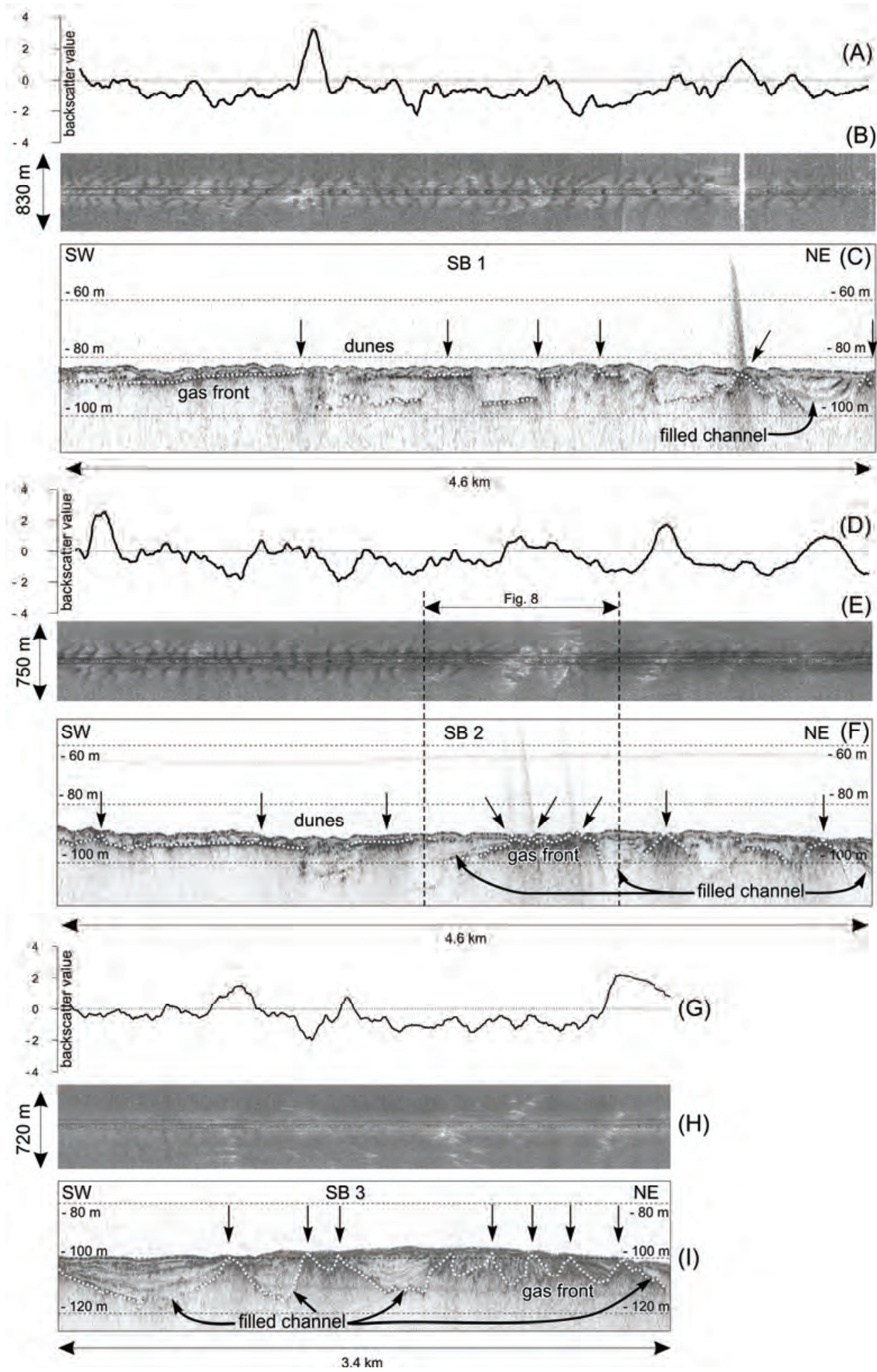

Figure 4.4. Three $5 \mathrm{kHz}$ subbottom profiles SB1, SB2 and SB3 (C, F and I) with their respective multibeamderived backscatter profiles (A, D and $\mathbf{G}$ ) and side scan sonar images (B, E and $\mathbf{H}$ ) (for location see Fig. 4.1.D.). Shallow gas fronts (dashed white line) occur at medium- and high-backscatter areas associated with seeps (arrows), whereas deep gas fronts occur at low-backscatter areas without seeps. Bubbles recorded as noise in the water column on the subbottom data (SB $1 \& 2$ ) sometimes blank out the side scan sonar recordings (see NE of SB1) (Fig. 4.4.B.).The extent of SB2 shown in Figure 4.8. is indicated. 

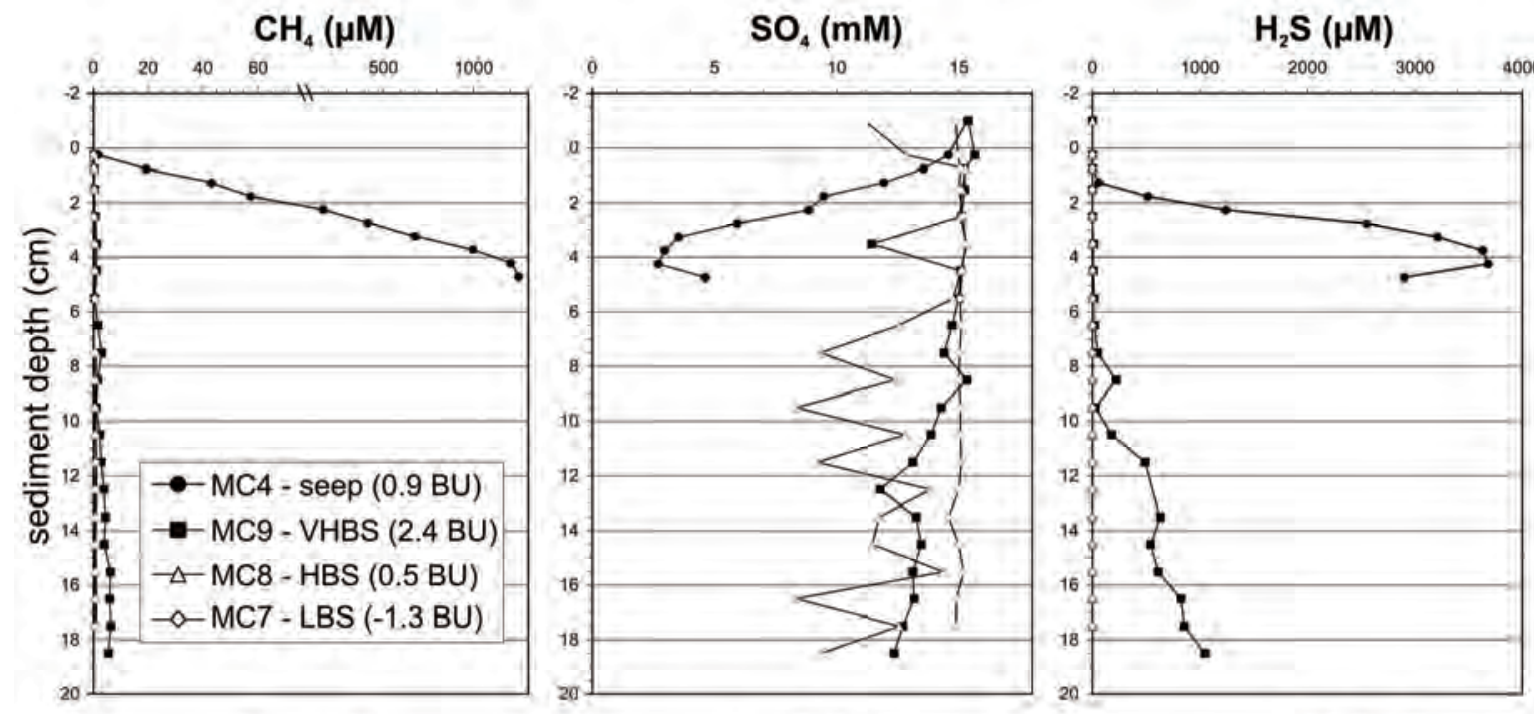

$\mathrm{NH}_{4}(\mu \mathrm{M})$
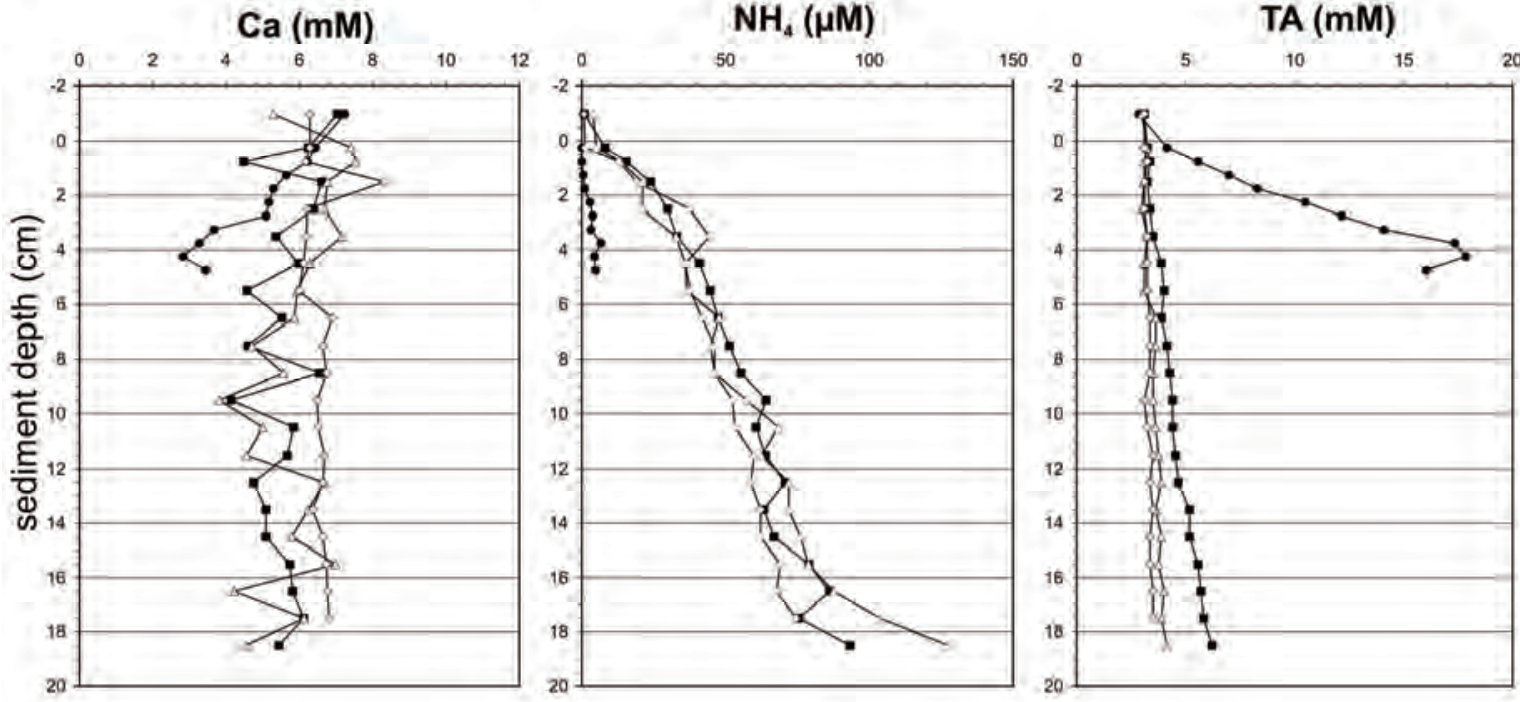

Figure 4.5. Pore-water data from multi-cores taken at different backscatter intensity sites. MC 4 was taken at an actively bubbling high-backscatter site. MC 7-9 are taken from areas with backscatter values ranging from low- to very-high-backscatter values. Values at $-1 \mathrm{~cm}$ depth are water samples taken from the core liner above the sediment surface (for locations see Figs. 4.1.D. and 4.2.).

fronts correspond to low-backscatter areas without seeps. This observation is valid for both the multibeam-derived backscatter profiles (Figs. 4.4.A., 4.4.D. and 4.4.G.) and the side scan sonar images (Figs. 4.4.B., 4.4.E. and 4.4.H.).

\subsubsection{Pore-water and grain-size analysis}

The pore-water analyses of the 4 multi-cores, taken at sites of different backscatter intensity, show significant differences (Fig. 4.5.). Core MC4 was taken directly at a bacterial mat with bubble release inside a high-backscatter area (0.9 BU), whereas MC7, MC8 and MC9 were taken in nonseeping low- to very-high-backscatter sites (-1.3 $\mathrm{BU}, 0.5 \mathrm{BU}$ and 2.4 BU, respectively) (Fig. 4.1.D. and Fig. 4.2.). It has to be stated that a core only represent a small subsample $\left(0.0314 \mathrm{~m}^{2}\right)$ of the area over which the backscatter value was measured $\left(25 \mathrm{~m}^{2}\right)$.

Core MC4 had limited penetration, with only 5 $\mathrm{cm}$ compared to at least $17 \mathrm{~cm}$ for the other three cores. Methane concentrations increase with depth in all four cores: very slightly in MC7 

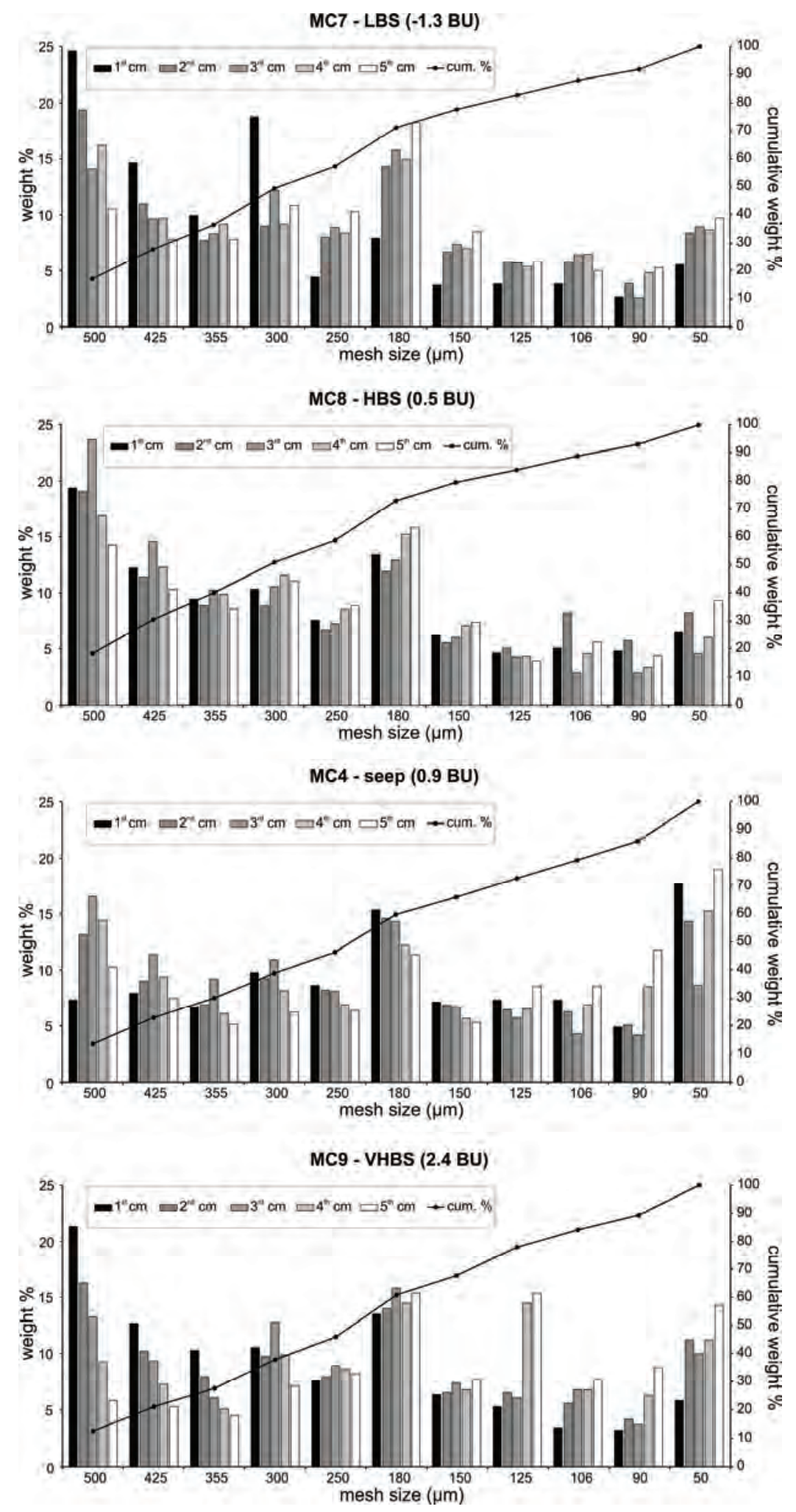

Figure 4.6. Grain-size data from multi-cores taken at different backscatter intensity sites shown as histograms and cumulative percentage curves for each centimeter of the uppermost $5 \mathrm{~cm}$. MC 4 was taken at an actively bubbling high-backscatter site. MC 7-9 are taken from areas with backscatter values ranging from low- to veryhigh-backscatter values (for locations see Figs. 1D and 2). 
and MC8, more in MC9 and very strongly in MC4 (Fig. 4.5.). Equivalent trends can be seen for the increase of sulfide and total alkalinity (TA) and the decrease of sulfate with depth (Fig. 4.5.).
Ammonium shows a constant increase with depth for MC7, MC8 and MC9; whereas the concentrations for MC4 are generally much lower with only a slight increase with depth (Fig.
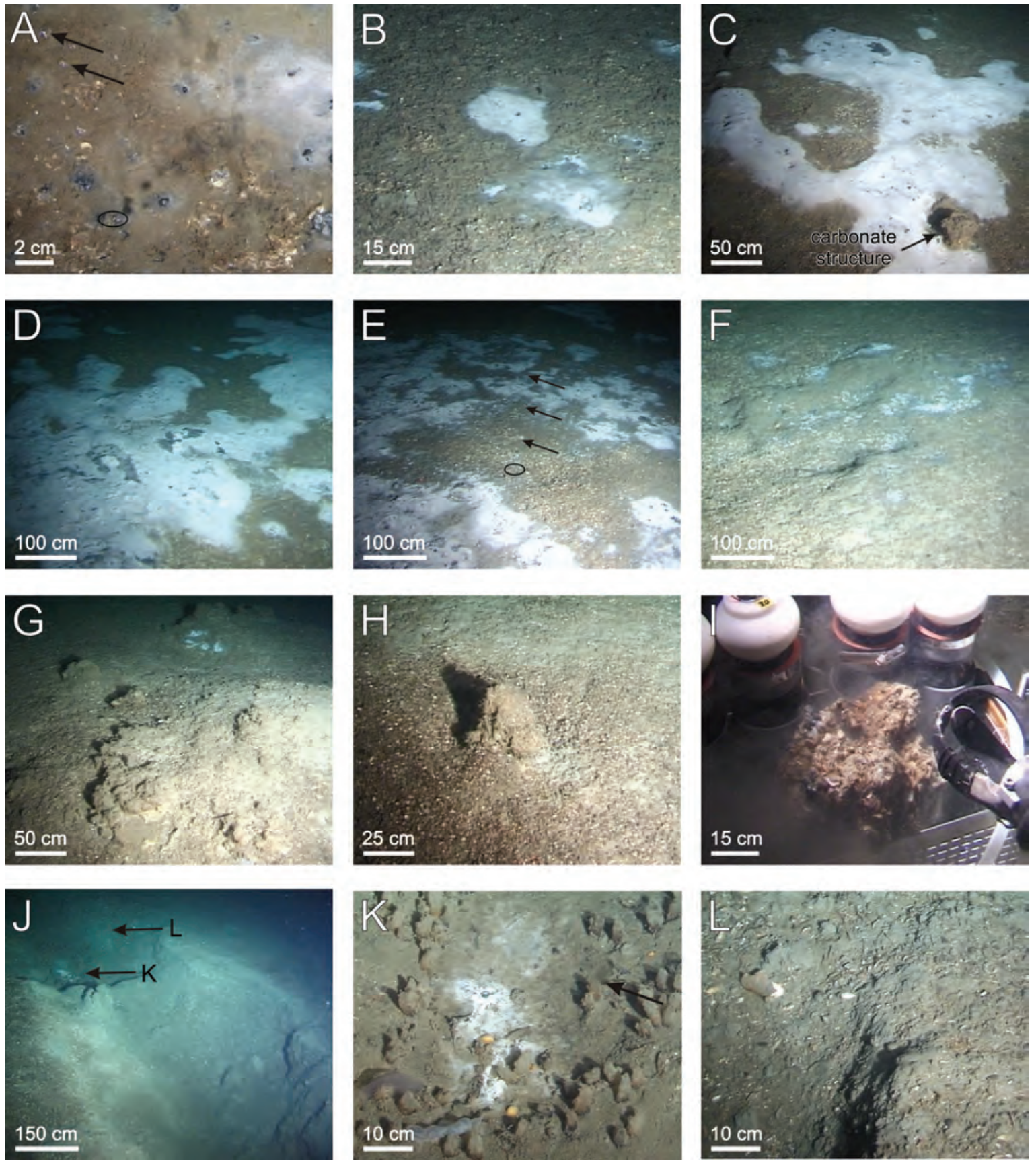

Figure 4.7. Screenshots captured from the JAGO dive 852 video (for outline of dive area see Fig. 4.2A) A-E: Bacterial mats of different sizes surrounding black venting holes all or not associated with bubble release (arrows) or carbonate structures. G-I: Semi-buried to fully-exposed carbonate structures, all or not associated with bacterial mats. J-L: Seafloor depression (pockmark) with rough, probably carbonate-cemented, edges and with a small bacterial mat on the bottom surrounded by Tunicates. Bubble release was observed on the right of the bacterial mat (arrow). 
4.5.). Calcium concentrations are relatively constant; only in MC4 a distinct decrease with depth is observed (Fig. 4.5.). In addition, water samples were taken from the core liner above the sediment surface. Cores MC4, MC8 and MC9 show changes between the pore-water and bottom-water data, whereas core MC7 almost shows no changes with respect to the bottomwater concentrations (Fig. 4.5.).

The grain-size analysis of the 4 multi-cores reveals very limited differences in grain-size distribution for the uppermost $5 \mathrm{~cm}$ of the different cores. The fraction coarser than $50 \mu \mathrm{m}$ only consists of shell fragments (Modiolus phaseolinus), up to centimeter scale, with rare carbonate-cemented sediments (shell fragments and fine-grained sediments). All cores are characterized by a polymodal grain-size distribution for the fraction between 600 and 50 $\mu \mathrm{m}$ (Fig. 4.6.).

\subsubsection{Visual seafloor observations}

Visual observations generally show a rather flat, featureless seafloor with a micro-relief of a few centimeters. In decimeter scale very little relief is present, except for a small depression/pockmark observed during the JAGO dive (Figs. 4.7. J.-L.). The sediment surface is typically composed of shells and shell fragments in a fine-grained matrix, as confirmed by the grain-size analyses (Figs. 4.7.A.-L. and Fig. 4.8.A.). Seeps are generally characterized by bubbles escaping from small black venting holes, which may or may not be surrounded by bacterial mats (possibly Beggiatoa sp.) (Fig. 4.7.A.). Bubbles are released either from within bacterial mats (Fig. 4.7.A.), from their edges (Fig. 4.7.K.) or from between bacterial mats if the mats occur in larger clusters (Fig. 4.7.E.). The bright white bacterial mats occur as irregularly shaped single patches or in clusters with sizes ranging from a couple of square centimeters to several square meters (Figs. 4.7.A.-F. and Figs. 4.8.B.-E.). JAGO's sampling claw revealed that quite often the sediment below bacterial mats is hard. The sediment usually gets softer within a few centimeters away from the mat. Digging underneath bacterial mats frequently exposed solid carbonate crusts or simply failed because the sediment was too hard. The distribution of the bacterial mats corresponds very well with the high-to very-high-backscatter areas and with shallow gas fronts (Fig. 4.9., for the extent of SB2 in Fig. 4.9. see Fig. 4.4.). Almost no bacterial mats occur within the low-backscatter areas. Generally, during the visual observations no bubbles were observed being released from the bacterial mats, which is in agreement with the absence of single-beam-detected seeps at the bacterial-mat locations (Fig. 4.9.).

Bacterial mats were also observed in association with carbonates that form positive elevations on the seafloor. Some only form a moderate relief of a couple of centimeters (Fig. 4.7.F. and Figs. 4.8.D. and F.), whereas other fully-exposed carbonate structures are irregularly shaped and tens of centimeters high and wide (Figs. 4.7.G.-I.). Areas around carbonates often show up as rougher surfaces resembling erosion features (Figs. 4.7.F.-G., Fig. 4.7.L. and Figs. 4.8.G.-I.), which correspond well with the high to very-high-backscatter areas.

\subsection{Discussion}

\subsubsection{Bacterial mats, carbonates and their relation to seep distribution}

Based on the visual observations and analysis of the core data, different stages of bacterialmat growth and authigenic carbonate formation can be determined. This process appears to lead to a gradual (self-)sealing of the seeps by carbonate clogging, followed by a relocation of the bubble-releasing locations. Our observations confirm the three-stage self-sealing process of seeps, proposed by Hovland (2002).

The self-sealing process starts with gas bubbles, generated from methanesupersaturated pore waters (Boudreau et al., 2001), being released into the water column from small holes in the sea bed (Fig. 4.7.A.). The venting holes generally have a dark color indicating the precipitation of sulfide minerals like pyrite (Peckmann et al., 2001) and are often surrounded by bacterial mats of different sizes (Figs. 4.7.A.-E.). These bacterial mats are formed by sulfide-oxidizing bacteria (e.g. Beggiatoa $s p$. ), 

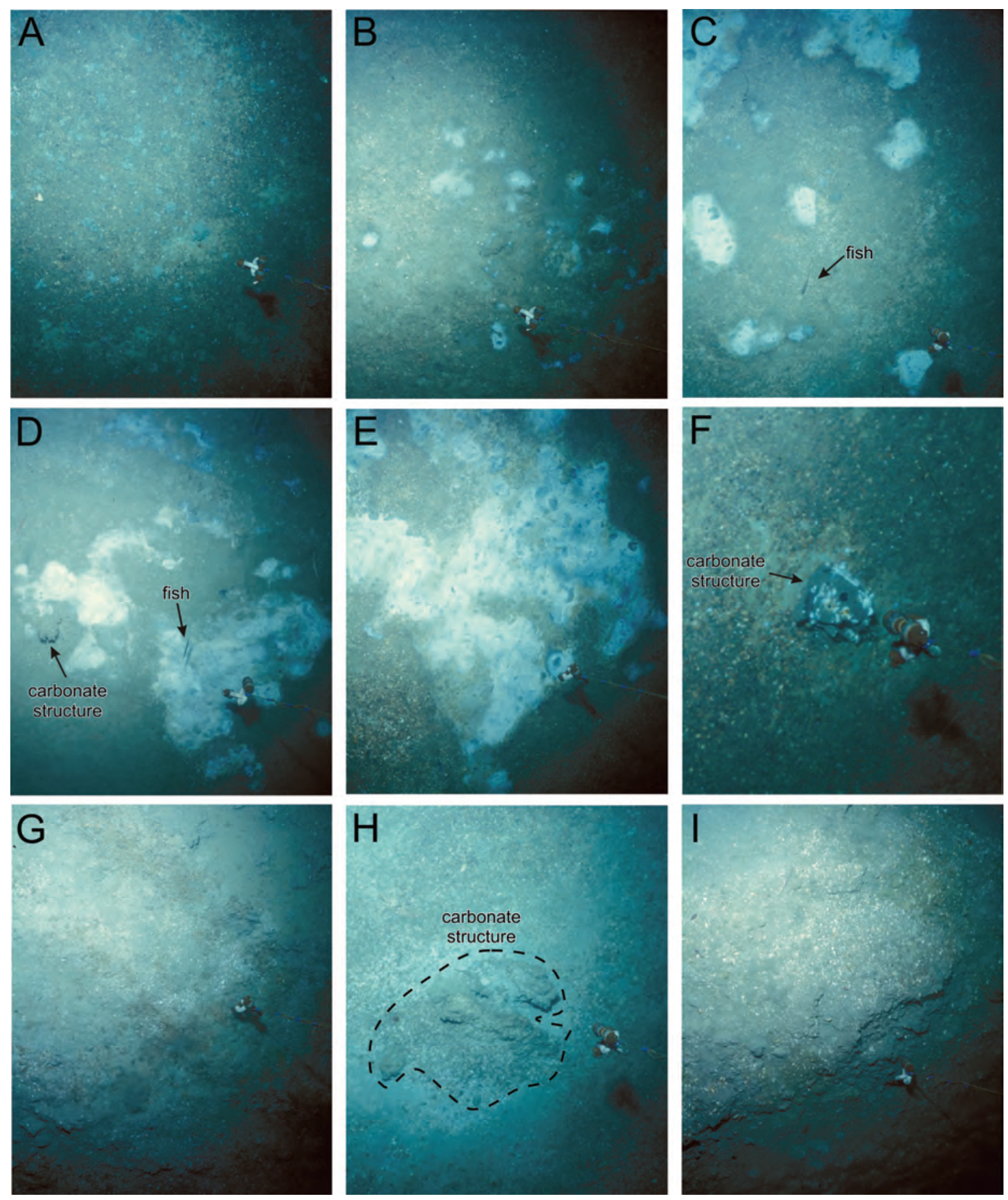

Figure 4.8. Screenshots taken during the OFOS video lines shown in Figure 4.9., characterizing the study-area seafloor (for scale see the 10 by $10 \mathrm{~cm}$ shackles). A: Usual flat, shell-covered, seafloor. B-E: Bacterial mats of different sizes. F-I: Carbonate formations showing up as solitary buildups with small bacterial mats or as rough, carbonate-cemented, seafloor.

which profit from the high fluxes of sulfide generated by the anaerobic oxidation of methane (AOM) (Boetius et al., 2000; Boetius and Suess, 2004; Sommer et al., 2006).

The pore-water analysis of MC4 shows typical profiles and concentrations indicative of AOM near the sediment surface, with strong gradients of increasing alkalinity, sulfide and methane concentrations (Fig. 4.5.). Decreasing sulfate and very low ammonium concentrations indicate 


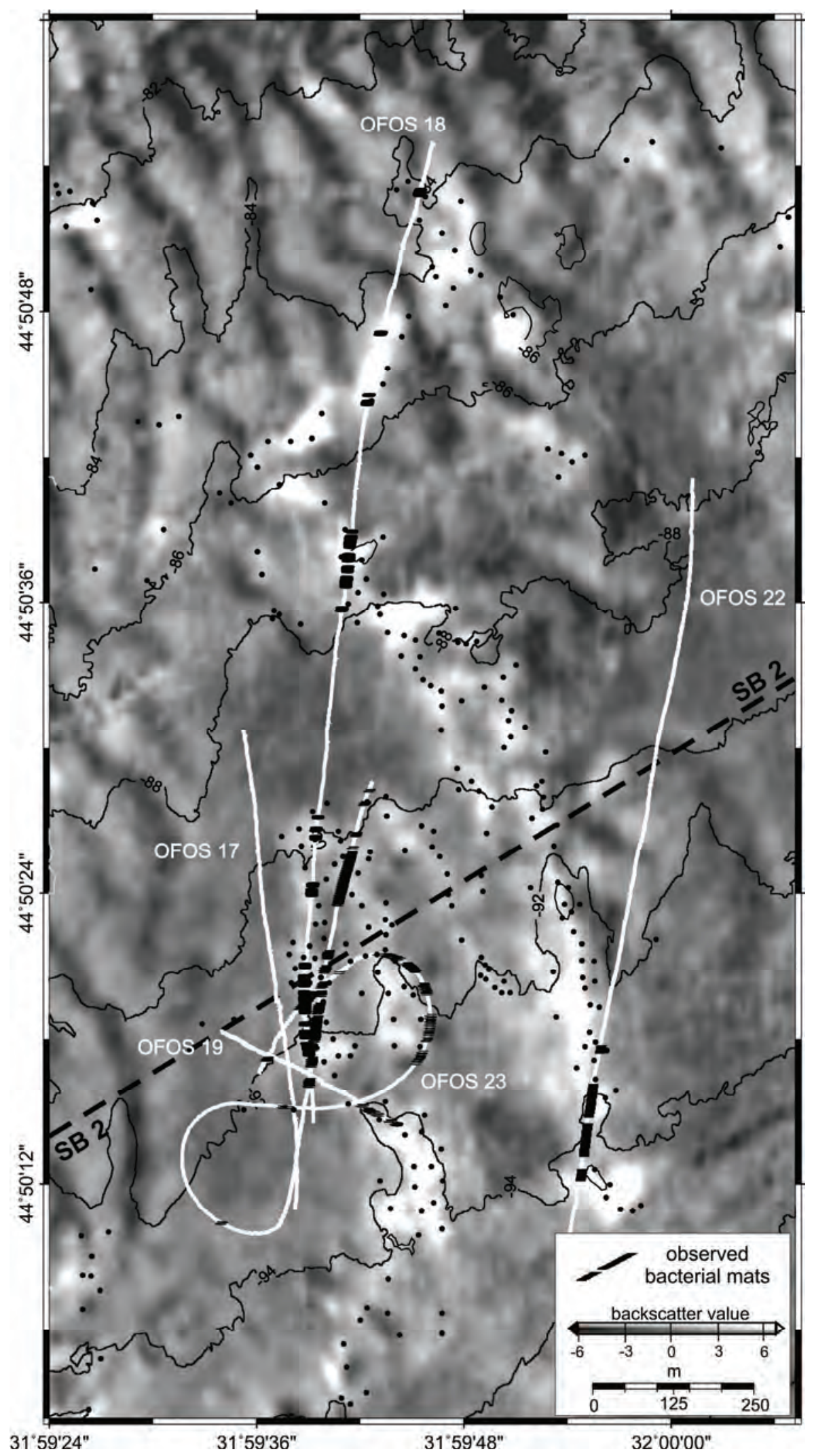

Figure 4.9. Multibeam backscatter map overlain with bathymetric contours (for location see Fig. 4.2.A.), seep locations (black dots) and the outline of seismic profile SB2 (see Fig. 4.1.D. and Fig. 4.4.). Visually observed bacterial mats are indicated by black markers along the offset-corrected OFOS video lines (white lines). Bacterial mats occur solely at high to very-high-backscatter areas. 
that AOM is the only sulfate-consuming process. From the other cores, only MC9 shows evidence of $A O M$, with changes in sulfate, sulfide and methane below $6 \mathrm{~cm}$ sediment depth. The sulfate decrease is 2.4 higher than the sulfide increase, pointing to precipitation of sulfides such as troilite or pyrite.

The bacterial mats may cover several square meters by capturing dissolved and free gas at venting locations (Figs. 4.7.A.-E. and Figs. 4.8.B.E.). This enhances $A O M$ in the sediments beneath the mats which facilitates their lateral growth (Boetius and Suess, 2004; Sommer et al., 2006).

AOM is typically associated with the formation of methane-derived authigenic carbonates (MDACs) (Hovland et al., 1985; Paull et al., 1992; Peckmann et al., 2001; Greinert et al., 2002a; Orange et al., 2002; Johnson et al., 2003; Mazzini et al., 2006; Judd and Hovland, 2007). Therefore, locations with increased methanerich fluid fluxes causing $A O M$ and bacterial-mat development, are often linked with MDAC formation, as was shown by JAGO sampling and visual observations (Figs. 4.7.C., 4.7.F.-G. and 4.7.J.-K., Figs. 4.8.D. and 4.8.F.). This also explains the limited penetration of MC4 and the decreasing calcium concentrations within this core, pointing to a calcium-rich carbonate formation. XRD analyses of recovered carbonate pieces from MC4 show aragonite as the dominant cementing carbonate phase. The carbonate-cementation of the seafloor sediments increases their resistance to erosion, thus enhancing seafloor roughness and resulting in exposed carbonate-cemented structures (Figs. 4.7.C., 4.7.F.-J. and 4.7.L., Figs. 4.8.D. and 4.8.F.-I.).

Once MDAC formation has started, ongoing precipitation may result in clogging fluid pathways and also blocking the migration of free gas through the sediments, thus forcing bubbles to migrate laterally towards the edge of the carbonate crust or carbonate-cemented sediments. Therefore bubbles are often released at the edge of large bacterial mats (Figs. 4.7.E. and 4.7.K.). Eventually, carbonate precipitation will lead to the self-sealing of the entire seep, leaving behind a carbonated-cemented seafloor with exposed and buried carbonates (Hovland, 2002), associated with only small or no bacterial mats, and no seeps (Figs. 4.7.F.-L. and Figs. 4.8.F.-I.).

\subsubsection{Controls on acoustic seafloor backscatter}

The high to very-high-backscatter areas in our study area often coincide with pockmarks, therefore the angle of incidence and the morphology of the seafloor could be a prime factor causing the high-backscatter return (Blondel and Murton, 1997). However, for the pockmarks as well as for the dunes, the differences in backscatter do not seem to be related to the morphology of these features. First of all, the backscatter data is acquired when sailing in all possible directions. If differences in backscatter response are caused by differences in morphology, this would give differences in backscatter response for different acquisition orientation. But this is not the case. Furthermore when comparing the backscatter data from low- and high-backscatter areas (Figs. 4.2.A. and 4.10.). The similar morphology of the seafloor together with the similar incidence angles along the swath for high- and lowbackscatter swaths clearly indicates that the observed difference in seafloor amplitude and the resulting normalized-backscatter strength between both swaths is morphologyindependent (Fig. 4.10.). Finally, the highbackscatter patches associated with seeps were also observed outside pockmarks on a flat seafloor (Fig. 4.2.A.). These observations indicate that the high to very-high-backscatter anomalies observed in our study area are not caused by morphological effects, but by differences in sediment properties, such as roughness, acoustic impedance or grain size at and around the seep sites (Blondel and Murton, 1997). For the dunes, the backscatter differences are most likely related to sedimentproperty differences between the sediments covering the western and eastern flanks of the dunes; e.g. difference in grain-size distribution induced by prevailing currents (Todd, 2005).

Since the medium- to high-backscatter areas seem to be related to shallow gas fronts, (Figs. 4.4. and 4.9.), gas bubbles captured close to the seafloor might increase the backscattering 

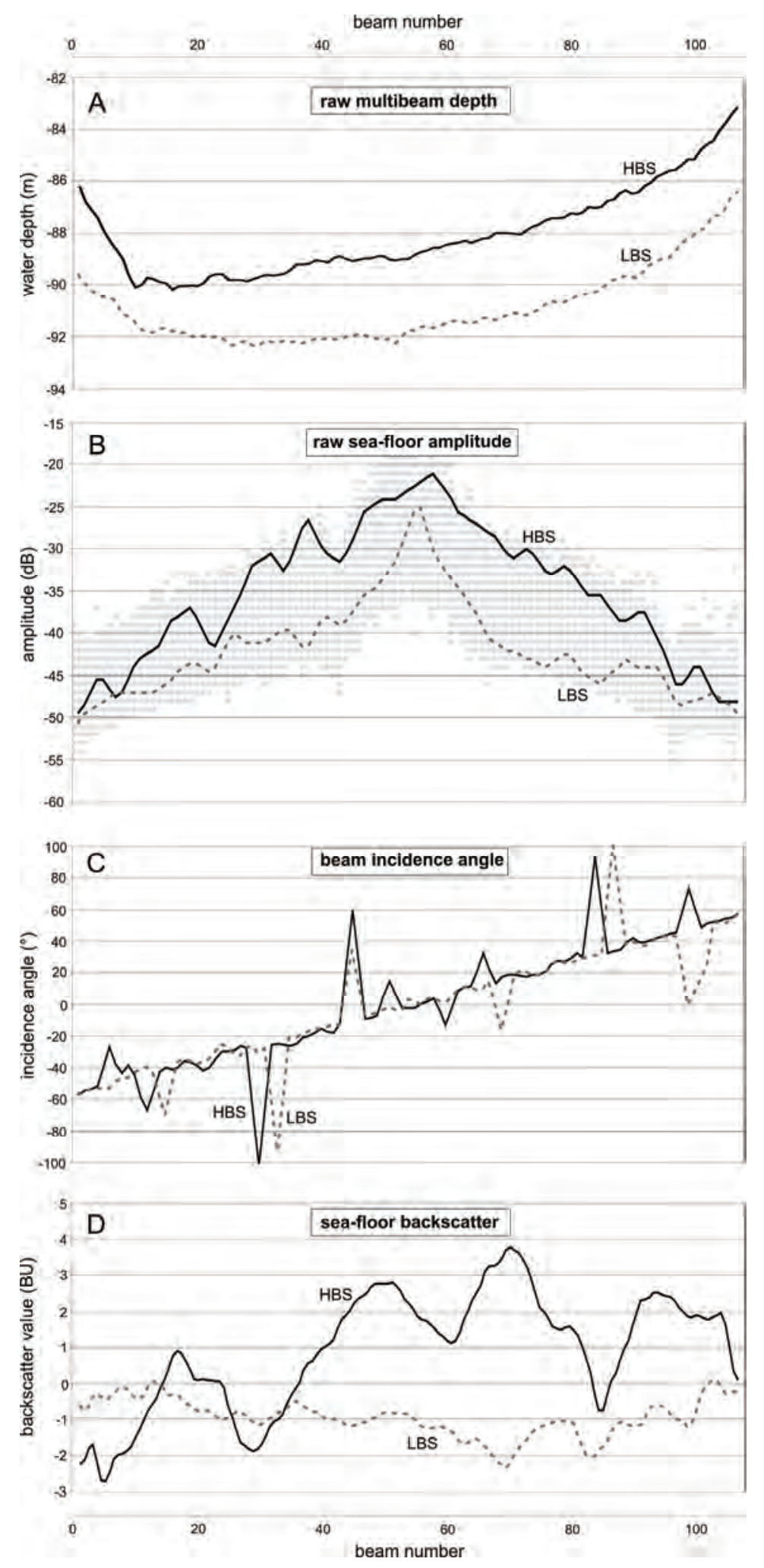

Figure 4.10. Comparison of two multibeam swaths from one multibeam line, one recorded in a highbackscatter area (full line) and one from a low- to medium-backscatter area (dotted line). A. The raw depth for both swaths (see Fig. 4.2.A. for location). B. The raw amplitude for both swaths within a cloud representing all amplitudes recorded during the particular multibeam line. $\mathbf{C}$. The incidence angle for each beam of both swaths. D. Normalized backscatter values for both swaths. 
because of the increased acoustic impedance affecting both the interface and volume backscattering (Fonseca, 2001; Fonseca et al., 2002). Fonseca et al. (2002) postulated, however, that in shallow water $(<100 \mathrm{~m}$ water depth) the interface backscatter is severely reduced due to the decrease in sediment sound speed. The gain in volume backscatter due to the presence of methane bubbles is insufficient to compensate for the loss in interface backscatter, resulting in a net decrease in the total backscatter response. Since the water depth in our study area is generally less than $100 \mathrm{~m}$, free gas present in the seafloor sediments can probably be discarded as the main factor for backscatter enhancement. This assumption is further sustained by our raw backscatter measurements, with differences up to $18 \mathrm{~dB}$ between low- and high-backscatter areas (Fig. 4.10.). Fonseca (2001) observed that sub-surface gas, even in $-785 \mathrm{~m}$ water depth, only leads to a $4 \mathrm{~dB}$ and $\mathrm{a} 7 \mathrm{~dB}$ gain in backscatter strength for a $95 \mathrm{kHz}$ and a $30 \mathrm{kHz}$ multibeam system respectively.

Grain-size or shell-fragment distribution as well as bioturbation can determine the acoustic backscatter response of the seafloor (Pouliquen and Lyons, 2002; Collier and Brown, 2005; Lyons, 2005). Since no signs of bioturbation were observed, bioturbation can be ruled out as a cause for the observed backscatter patterns. Grain-size and shell fragment distribution could be of importance since the fraction $>50 \mu \mathrm{m}$ consist solely of shell fragments. However, the difference in grain-size distribution between the cores is too small to cause the observed differences in backscatter response.

Authigenic carbonates are known to be major contributors to seafloor roughness and acoustic impedance contrast in seep areas, and thus also to acoustic backscatter intensity (Orange et al., 2002; Johnson et al., 2003; Holland et al., 2006). Holland et al. (2006) shows that authigenic carbonate structures lead to a backscatter increase of 10-15 dB above background measurements. This is very similar to our raw backscatter measurements, with differences of up to $18 \mathrm{~dB}$ between low- and high-backscatter areas (Fig. 4.10.). This suggests, together with the lack of other backscatter enhancers, that for our study area the observed authigenic carbonates are probably the main reason for the high to very-high-backscatter patches.

\subsubsection{Backscatter, seep distribution and sub-surface integrative model}

When disregarding the backscatter pattern caused by the sediment dunes and the acquisition artifacts, we can conclude from our data, that the remaining backscatter anomalies are mainly caused by the presence of authigenic carbonates. Since ongoing carbonate formation causes a self-sealing of seep sites and a subsequent relocation of fluid pathways/seeps we conclude that the observed seafloor backscatter and seep distribution in our study area can be explained by the degree of authigenic carbonate formation (Fig. 4.11.).

Considering the formation of MDACs beneath bacterial mats and the non-seeping of most of these observed bacterial mats it can be concluded that the very-high-backscatter patches correspond to areas where intense/long-lived methane seepage has favored MDAC formation, which in turn has led to the self-sealing of these seep areas (Figs. 4.9. and 4.11.). Based on this, the high- and mediumbackscatter distribution can be interpreted as representing different stages of carbonate cementation (Fig. 4.11.). Locations with active methane seepage and ongoing carbonate precipitation show up as medium- to highbackscatter areas, whereas those with advanced, massive carbonate cementation -and due to the self-sealing possibly lower seep activity- are characterized by very high and maximum backscatter values. These very-highbackscatter areas are the result of long-lived and/or intensive seepage which resulted in the precipitation of massive MDACs and sometimes in the formation of pockmarks, due to finegrained sediment remobilization.

On a larger scale, the filled delta channels that control shallow gas migration and seep occurrence (Naudts et al., 2006) also determine the distribution of the seep-related backscatter anomalies; areas with deep sub-surface gas fronts and the absence of active seepage, correspond to low-backscatter areas (Figs. 4.4. and 4.11.). The medium- to high-backscatter 


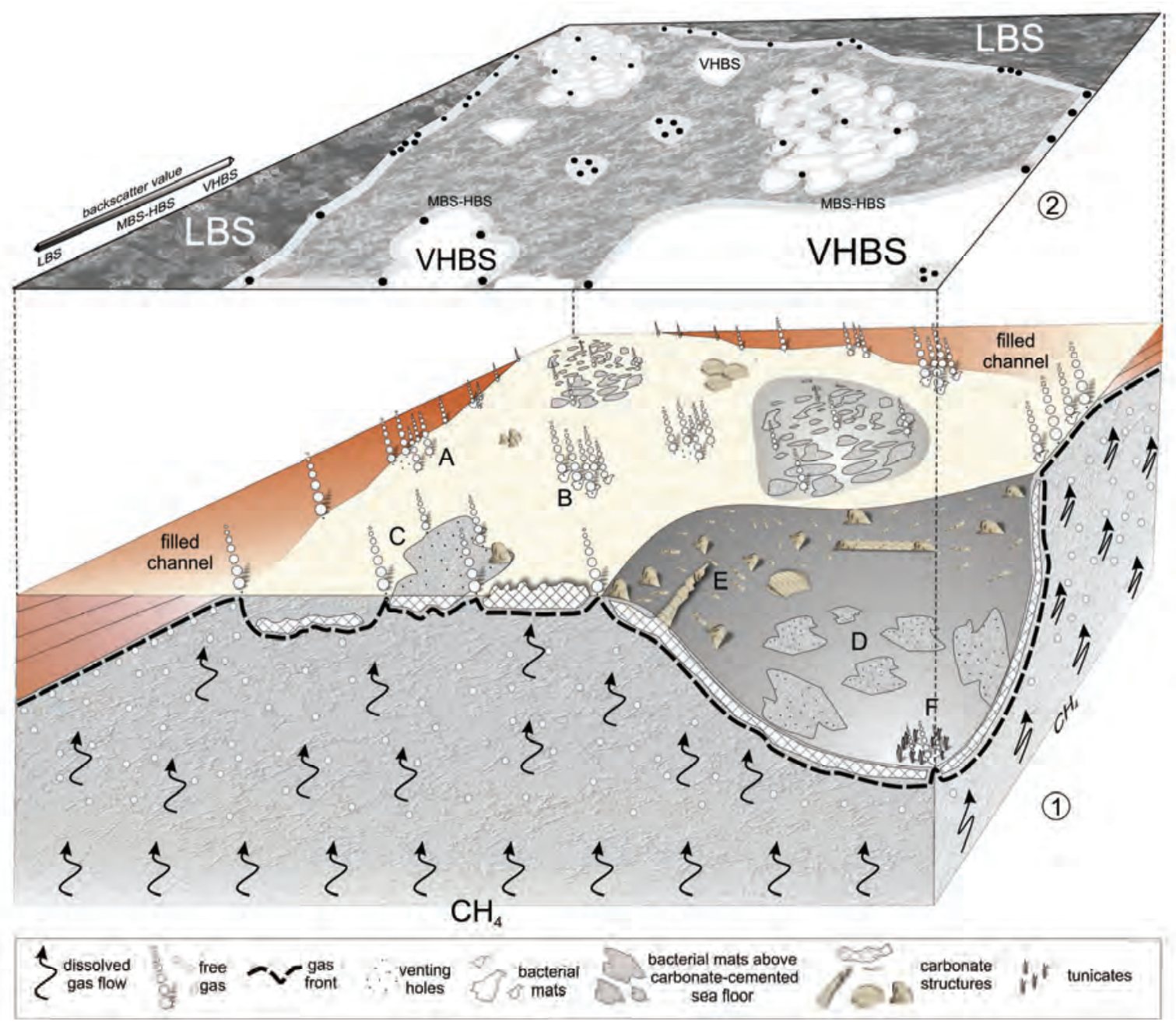

Figure 4.11. Overview model of the supposed fluid migration in the subsurface, carbonate formation with seep relocation and the acoustic seafloor backscatter expression. (1) A. Gas-bubble release from black venting holes. B. Bacterial-mat formation around the black venting holes. C-D. Precipitation of methane-derived authigenic carbonates underneath bacterial mats with subsequent relocation or termination of seepage. E. Semi-buried to fully exposed methane-derived authigenic carbonate structures. F. Bacterial mats with limited gas-bubble release and associated with chemosynthetic communities (e.g. Tunicates). All mentioned features can occur in association with or without pockmark formation. (2) Acoustic seafloor backscatter expression resulting from the seep distribution and associated features. Filled channels, blocking fluid migration, are characterized by low backscatter values (LBS) and the absence of seeps. Locations with active seepage and ongoing authigenic carbonate precipitation show up as medium- to high-backscatter areas (MBS), whereas those with advanced, massive carbonate precipitation and at present less or no seep activity show up as very high to maximum backscatter areas (VHBS).

areas only occur in between the channels, where the sub-surface gas front reaches the sediment-water interface and where active seepage takes place, accompanied by bacterialmat growth and authigenic carbonate formation, as a result of the higher methane fluxes and the associated AOM (Fig. 4.11.).

\subsection{Conclusions}

The 600 active methane bubble-releasing seeps that were detected in an area of $14.73 \mathrm{~km}^{2}$ on the continental shelf of the Dnepr paleo delta occur systematically in areas that are characterized by a higher-than-average acoustic backscatter response on side scan sonar and/or multibeam echosounder recordings. Detailed 
spatial analysis shows that the seeps occur preferentially in areas with medium- to highbackscatter strength, but not in areas with very high and maximum backscatter strength.

Visual observations made with the JAGO submersible and OFOS video sled showed that the high-backscatter areas are characterized by the occurrence of bacterial mats and methanederived authigenic carbonates (MDACs) in the seafloor sediments, both indicative of AOM. This was confirmed by pore-water analyses, which showed increasing methane, total alkalinity and sulfide concentrations in correspondence with decreasing sulfate concentrations and no increase in ammonium.

Complete integration of all available data excluded morphology, grain-size distribution and the presence of free gas bubbles in the shallow subsurface as possible causes for the observed high backscatter associated with the active seeps. Instead we conclude that the highbackscatter values in areas with active methane bubble release are caused by the presence of methane-derived authigenic carbonates in the sediment. The absence of active seeps in areas with the highest backscatter values supports the model proposed by Hovland (2002), in which AOM-induced carbonate formation may lead to (self-)sealing of fluid pathways by carbonate clogging, followed by a relocation of the fluid/gas pathways around the cemented, impermeable areas. As a final point, our analysis shows that acoustic backscatter of the seafloor can indeed be used as a proxy -and as a rapid mapping tool- for detecting seep provinces that are very likely actively seeping. Furthermore, areas with the highest backscatter values should be excluded from backscatter-based estimations of the total area involved in active seepage.

\section{Acknowledgements}

We thank the captain and the crew of the $58^{\text {th }}$ and $60^{\text {th }}$ cruise of RV Professor Vodyanitskiy for their hard work and their hospitality and L-3 ELAC Nautik GMBH for their superior and fast support. We like to thank Matthias Haeckel for his help with the pore-water analysis. This study was carried out in the framework of the CRIMEA project (EC project EVK-2-CT-2002-00162; http://www.CRIMEA-info.org) and of a Bilateral Flanders-Russian Federation Project (Gas hydrate accumulations associated with active fluid seeps: a combined thermal and acoustic approach). JAGO dive 852 was carried out in the framework of the METROL project (EC project EVK3-CT-2002-00080). We also like to thank SMT (Kingdom Suite) and IVS (Fledermaus) for the academic licenses. Finally we thank Martin Hovland, David Piper and two anonymous reviewers for their constructive reviews which helped improve this manuscript.

\section{Additional information}

Lieven Naudts processed and interpreted most of the datasets, wrote the manuscript and made most figures. The pore-water data and figure was provided by Jens Greinert and Stan E. Beaubien. Lieven Naudts also assisted with the data acquisition during the 12 weeks of expedition on RV Vodyanitskiy in 2003 and 2004. Co-authors helped by reviewing the manuscript and/or by providing the datasets. For the processing of the multibeam data assistance was given by Jens Greinert. For processing of the seismic data assistance was given by Peter Staelens.

\section{References}

Amouroux, D., Roberts, G., Rapsomanikis, S., Andreae, M.O., 2002. Biogenic Gas (CH4, N2O, DMS) Emission to the Atmosphere from Near-shore and Shelf Waters of the North-western Black Sea. Estuarine, Coastal Shelf Sci. 54, 575-587.

Artemov, Y.G., 2006. Software support for investigation of natural methane seeps by hydroacoustic method. Mar. Ecol. J., 57-71.

Artemov, Y.G., Egorov, V., Polikarpov, N., Gulin, S.B., 2007. Methane emission to the hydro- and atmosphere by gas bubble streams in the Dnieper paleo-delta, the Black Sea. Reports of the Natl. Acad. of Sci. of Ukraine 5, 110-116. 
Bange, H.W., 2006. Nitrous oxide and methane in European coastal waters. Estuarine, Coastal Shelf Sci. 70, 361-374.

Blondel, P., Murton, B.J., 1997. Handbook of Seafloor Sonar Imagery. Wiley-Praxis Series in Remote Sensing. John Wiley and Sons Ltd. in association with Praxis Publishing Ltd., Chichester. 314 pp.

Boetius, A., Ravenschlag, K., Schubert, C.J., Rickert, D., Widdel, F., Gieseke, A., Amann, R., Jorgensen, B.B., Witte, U., Pfannkuche, O., 2000. A marine microbial consortium apparently mediating anaerobic oxidation of methane. Nature 407, 623-626.

Boetius, A., Suess, E., 2004. Hydrate Ridge: a natural laboratory for the study of microbial life fueled by methane from near-surface gas hydrates. Chem. Geol. 205, 291-310.

Boudreau, B.P., Gardiner, B.S., Johnson, B.D., 2001. Rate of growth of isolated bubbles in sediments with a diagenetic source of methane. Limnol. Oceanogr. 46, 616-622.

Collier, J.S., Brown, C.J., 2005. Correlation of sidescan backscatter with grain size distribution of surficial seabed sediments. Mar. Geol. 214, 431-449.

Dimitrov, L., 2002. Contribution to atmospheric methane by natural seepages on the Bulgarian continental shelf. Cont. Shelf Res. 22, 2429-2442.

Egorov, V., Luth, U., Luth, C., Gulin, M.B., 1998. Gas seeps in the submarine Dnieper Canyon, Black Sea: acoustic, video and trawl data. In: U. Luth, C. Luth and H. Thiel (Editors), MEGASEEPS Gas Explorations in the Black Sea, Project Report. Zentrum für Meres- und Klimaforschung der Universität Hamburg, Hamburg, pp. 11-21.

Etiope, G., 2004. New Directions: GEM--Geologic Emissions of Methane, the missing source in the atmospheric methane budget. Atmos. Environ. 38, 3099-3100.

Etiope, G., Klusman, R.W., 2002. Geologic emissions of methane to the atmosphere. Chemosphere 49, 777-789.

Fonseca, L., 2001. A model for backscattering angular response of gassy sediments: Applications to petroleum exploration and development programs. Ph.D. Thesis, University of New Hampshire, 126 pp.

Fonseca, L., Mayer, L., Orange, D., Driscoll, N., 2002. The high-frequency backscattering angular response of gassy sediments: Model/data comparison from the Eel River Margin, California. J. Acoust. Soc. Am. 111, 2621-2631.

Garcia-Gil, S., Vilas, F., Garcia-Garcia, A., 2002. Shallow gas features in incised-valley fills (Ria de Vigo, NW Spain): a case study. Cont. Shelf Res. 22, 2303-2315.

Gay, A., Lopez, M., Ondreas, H., Charlou, J.L., Sermondadaz, G., Cochonat, P., 2006. Seafloor facies related to upward methane flux within a Giant Pockmark of the Lower Congo Basin. Mar. Geol. 226, 81-95.

Grasshoff, K., Ehrhardt, M., Kremling, K., 1999. Methods of seawater analysis. Verlag Chemie, Weinheim.

Greinert, J., Bohrmann, G., Elvert, M., 2002a. Stromatolitic fabric of authigenic carbonate crusts: result of anaerobic methane oxidation at cold seeps in 4,850 m water depth. Int. J. Earth Sci. 91, 698-711.

Greinert, J., Bohrmann, G., Suess, E., 2001. Gas hydrate-associated carbonates and methane-venting at Hydrate Ridge: Classification, distribution, and origin of authigenic lithologies. In: C.K. Paull and W.P. Dillon (Editors), Natural Gas Hydrates: Occurrence, Distribution, and Detection, Geophysical Monograph. American Geophysical Union, pp. 99-113.

Greinert, J., Bollwerk, S.M., Derkachev, A., Bohrmann, G., Suess, E., 2002b. Massive barite deposits and carbonate mineralization in the Derugin Basin, Sea of Okhotsk: precipitation processes at cold seep sites. Earth Planet. Sci. Lett. 203, 165-180.

Greinert, J., McGinnis, D.F., Naudts, L., Linke, P., De Batist, M., 2010. Atmospheric methane flux from bubbling seeps: Spatially extrapolated quantification from a Black Sea shelf area. J. Geophys. Res. 115, 1-18. 
Holland, C.W., Weber, T.C., Etiope, G., 2006. Acoustic scattering from mud volcanoes and carbonate mounds. J. Acoust. Soc. Am. 120, 3553-3565.

Hornafius, J.S., Quigley, D., Luyendyk, B.P., 1999. The world's most spectacular marine hydrocarbon seeps (Coal Oil Point, Santa Barbara Channel, California): Quantification of emissions. J. Geophys. Res., Oceans 104, 20703-20711.

Hovland, M., 1991. Large Pockmarks, Gas-Charged Sediments and Possible Clay Diapirs in the Skagerrak. Mar. Pet. Geol. 8, 311-316.

Hovland, M., 1992. Hydrocarbon seeps in northern marine waters; their occurrence and effects. Palaios 7, 376-382.

Hovland, M., 2002. On the self-sealing nature of marine seeps. Cont. Shelf Res. 22, 2387-2394.

Hovland, M., Judd, A.G., Burke, R.A., 1993. The Global Flux of Methane from Shallow Submarine Sediments. Chemosphere 26, 559-578.

Hovland, M., Talbot, M., Olaussen, S., Aasberg, L., 1985. Recently formed methane-derived carbonates from the North Sea floor. In: B.M. Thomas (Editor), Petroleum Geochemistry in Exploration of the Norwegian Shelf. Norwegian Petroleum Society. Graham and Trotman, pp. 263-266.

IPCC, 2001a. Climate Change 2001: Synthesis Report. A Contribution of Working Groups I, II, and III to the Third Assessment Report of the Intergovernmental Panel on Climate Change. Cambridge University Press, Cambridge, United Kingdom and New York, NY, USA. 398 pp.

IPCC, 2001b. Climate Change 2001: The Scientific Basis. Contribution of Working Group I to the Third Assessment. Cambridge University Press, Cambridge, United Kingdom and New York, NY, USA. $881 \mathrm{pp}$.

Ivanov, M., Blinova, V., Kozlova, E., Westbrook, G.K., Mazzini, A., Minshull, T.A., Nouzé, H., 2007. First Sampling of Gas Hydrate From the Vøring Plateau. Eos Trans. Am. Geophys. Union 88, 209.

Johnson, J.E., Goldfinger, C., Suess, E., 2003. Geophysical constraints on the surface distribution of authigenic carbonates across the Hydrate Ridge region, Cascadia margin. Mar. Geol. 202, 79120.

Judd, A., Hovland, M., 2007. Seabed fluid flow: the impact on geology, biology and the marine environment. Cambridge University Press, Cambridge. $475 \mathrm{pp}$.

Judd, A.G., 2004. Natural seabed gas seeps as sources of atmospheric methane. Environ. Geol. (Berlin) 46, 988-996.

Judd, A.G., Hovland, M., 1992. The Evidence of Shallow Gas in Marine-Sediments. Cont. Shelf Res. 12, 1081-1095.

Kessler, J.D., Reeburgh, W.S., Southon, J., Seifert, R., Michaelis, W., Tyler, S.C., 2006. Basin-wide estimates of the input of methane from seeps and clathrates to the Black Sea. Earth Planet. Sci. Lett. 243, 366-375.

Klaucke, I., Sahling, H., Weinrebe, W., Blinova, V., Burk, D., Lursmanashvili, N., Bohrmann, G., 2006. Acoustic investigation of cold seeps offshore Georgia, eastern Black Sea. Mar. Geol. 231, 5167.

Krastel, S., Spiess, V., Ivanov, M., Weinrebe, W., Bohrmann, G., Shashkin, P., Heidersdorf, F., 2003. Acoustic investigations of mud volcanoes in the Sorokin Trough, Black Sea. Geo-Mar. Lett. V23, 230-238.

Kruglyakova, R.P., Byakov, Y.A., Kruglyakova, M.V., Chalenko, L.A., Shevtsova, N.T., 2004. Natural oil and gas seeps on the Black Sea floor. Geo-Mar. Lett. V24, 150-162.

Kutas, R.I., Paliy, S.I., Rusakov, O.M., 2004. Deep faults, heat flow and gas leakage in the northern Black Sea. Geo-Mar. Lett. V24, 163-168.

Kvenvolden, K.A., Rogers, B.W., 2005. Gaia's breath--global methane exhalations. Mar. Pet. Geol. 22, 579-590.

Leifer, I., Patro, R.K., 2002. The bubble mechanism for methane transport from the shallow sea bed to the surface: A review and sensitivity study. Cont. Shelf Res. 22, 2409-2428. 
Lelieveld, J., Crutzen, P.J., Dentener, F.J., 1998. Changing concentration, lifetime and climate forcing of atmospheric methane. Tellus, Ser. B. 50, 128-150.

Luth, C., Luth, U., Gebruk, A.V., Thiel, H., 1999. Methane gas Seeps Along the Oxic/Anoxic Gradient in the Black Sea: Manifestations, Biogenic Sediment Compounds and Preliminary Results on Benthic Ecology. Mar. Ecol. 20, 221-249.

Luyendyk, B., Kennett, J., Clark, J.F., 2005. Hypothesis for increased atmospheric methane input from hydrocarbon seeps on exposed continental shelves during glacial low sea level. Mar. Pet. Geol. 22, 591-596.

Lyons, A.P., 2005. The potential impact of shell fragment distributions on high-frequency seafloor backscatter. IEEE J. Oceanic Eng. 30, 843-851.

MacDonald, I.R., Leifer, I., Sassen, R., Stine, P., Mitchell, R., Guinasso, N., 2002. Transfer of hydrocarbons from natural seeps to the water column and atmosphere. Geofluids 2, 95-107.

Mazzini, A., Svensen, H., Hovland, M., Planke, S., 2006. Comparison and implications from strikingly different authigenic carbonates in a Nyegga complex pockmark, G11, Norwegian Sea. Mar. Geol. 231, 89-102.

McGinnis, D.F., Greinert, J., Artemov, Y., Beaubien, S.E., Wuest, A., 2006. Fate of rising methane bubbles in stratified waters: How much methane reaches the atmosphere? J. Geophys. Res., Oceans 111.

Michaelis, W., Seifert, R., Nauhaus, K., Treude, T., Thiel, V., Blumenberg, M., Knittel, K., Gieseke, A., Peterknecht, K., Pape, T., Boetius, A., Amann, R., Jorgensen, B.B., Widdel, F., Peckmann, J., Pimenov, N.V., Gulin, M.B., 2002. Microbial Reefs in the Black Sea Fueled by Anaerobic Oxidation of Methane. Science 297, 1013-1015.

Naudts, L., Greinert, J., Artemov, Y., Staelens, P., Poort, J., Van Rensbergen, P., De Batist, M., 2006. Geological and morphological setting of 2778 methane seeps in the Dnepr paleo-delta, northwestern Black Sea. Mar. Geol. 227, 177-199.

Niemann, H., Elvert, M., Hovland, M., Orcutt, B., Judd, A., Suck, I., Gutt, J., Joye, S., Damm, E., Finster, K., Boetius, A., 2005. Methane emission and consumption at a North Sea gas seep (Tommeliten area). Biogeosciences 2, 335-351.

Oguz, T., 2002. Role of physical processes controlling oxycline and suboxic layer structures in the Black Sea. Global Biogeochem. Cycles 16.

Orange, D.L., Breen, N.A., 1992. The Effects of Fluid Escape on Accretionary Wedges. 2. Seepage Force, Slope Failure, Headless Submarine Canyons, and Vents. J. Geophys. Res. Solid Earth 97, 9277-9295.

Orange, D.L., Yun, J., Maher, N., Barry, J., Greene, G., 2002. Tracking California seafloor seeps with bathymetry, backscatter and ROVs. Cont. Shelf Res. 22, 2273-2290.

Pape, T., Blumenberg, M., Seifert, R., Egorov, V.N., Gulin, S.B., Michaelis, W., 2005. Lipid geochemistry of methane-seep-related Black Sea carbonates. Palaeogeogr. Palaeoclimatol. Palaeoecol. 227, 31-47.

Paull, C.K., Chanton, J.P., Neumann, A.C., Coston, J.A., Martens, C.S., Showers, W., 1992. Indicators of methane-derived carbonates and chemosynthetic organic carbon deposits; examples from the Florida Escarpment. Palaios 7, 361-375.

Peckmann, J., Reimer, A., Luth, U., Luth, C., Hansen, B.T., Heinicke, C., Hoefs, J., Reitner, J., 2001. Methane-derived carbonates and authigenic pyrite from the northwestern Black Sea. Mar. Geol. 177, 129-150.

Pimenov, N.V., Ivanova, A.E., 2005. Anaerobic Methane Oxidation and Sulfate Reduction in Bacterial Mats on Coral-Like Carbonate Structures in the Black Sea. Microbiology 74, 362-370.

Pimmel, A., Claypool, G., 2001. Introduction to shipboard organic geochemistry on the JOIDES Resolution, Texas A\&M University.

Polikarpov, G.G., Egorov, V.N., Gulin, S.B., Gulin, M.B., Stokozov, N.A., 1992. Gas seeps from the bottom of the Black Sea-a new object of molismology. In: G.G. Polikarpov (Editor), Molismology of the Black Sea. Nauka, Kiev pp. 10-28. 
Polikarpov, G.G., Egorov, V.N., Nezhdanonv, A.I., Gulin, S.B., Kulev, Y.D., Gulin, M.B., 1989. Methane gas seeps in the Black Sea-a new object of molismology. In: G.G. Polikarpov (Editor), Molismology of the Black Sea. Nauka, Kiev pp. 10-20.

Popescu, I., Lericolais, G., Panin, N., Normand, A., Dinu, C., Le Drezen, E., 2004. The Danube submarine canyon (Black Sea): morphology and sedimentary processes. Mar. Geol. 206, 249265.

Pouliquen, E., Lyons, A.P., 2002. Backscattering from bioturbated sediments at very high frequency. IEEE J. Oceanic Eng. 27, 388-402.

Reitner, J., Peckmann, J., Blumenberg, M., Michaelis, W., Reimer, A., Thiel, V., 2005. Concretionary methane-seep carbonates and associated microbial communities in Black Sea sediments. Palaeogeogr. Palaeoclimatol. Palaeoecol. 227, 18-30.

Ritger, S., Carson, B., Suess, E., 1987. Methane-Derived Authigenic Carbonates Formed by Subduction Induced Pore-Water Expulsion Along the Oregon Washington Margin. Geol. Soc. Am. Bull. 98, 147-156.

Rollet, N., Logan, G.A., Kennard, J.M., O'Brien, P.E., Jones, A.T., Sexton, M., 2006. Characterisation and correlation of active hydrocarbon seepage using geophysical data sets: An example from the tropical, carbonate Yampi Shelf, Northwest Australia. Mar. Pet. Geol. 23, 145-164.

Sager, W.W., MacDonald, I.R., Hou, R., 2003. Geophysical signatures of mud mounds at hydrocarbon seeps on the Louisiana continental slope, northern Gulf of Mexico. Mar. Geol. 198, 97-132.

Schmale, O., Greinert, J., Rehder, G., 2005. Methane emission from high-intensity marine gas seeps in the Black Sea into the atmosphere. Geophys. Res. Lett. 32.

Shoji, H., Soloviev, V., Matveeva, T., Mazurenko, L., Minami, H., Hachikubo, A., Sakagami, H., Hyakutake, K., Kaulio, V., Gladysch, V., Logvina, E., Obzhirov, A., Baranov, B., Khlystov, O., Biebow, N., Poort, J., Jin, Y.K., Kim, Y., 2005. Hydrate-Bearing Structures in the Sea of Okhotsk. Eos Trans. Am. Geophys. Union 86, 13-18.

Sommer, S., Pfannkuche, O., Linke, P., Luff, R., Greinert, J., Drews, M., Gubsch, S., Pieper, M., Poser, M., Viergutz, T., 2006. Efficiency of the benthic filter: Biological control of the emission of dissolved methane from sediments containing shallow gas hydrates at Hydrate Ridge. Global Biogeochem. Cycles 20.

Thiel, V., Peckmann, J., Richnow, H.H., Luth, U., Reitner, J., Michaelis, W., 2001. Molecular signals for anaerobic methane oxidation in Black Sea seep carbonates and a microbial mat. Mar. Chem. 73, 97-112.

Todd, B.J., 2005. Morphology and composition of submarine barchan dunes on the Scotian Shelf, Canadian Atlantic margin. Geomorphology 67, 487-500.

Treude, T., Knittel, K., Blumenberg, M., Seifert, R., Boetius, A., 2005. Subsurface Microbial Methanotrophic Mats in the Black Sea. Appl Environ Microbiol 71, 6375-6378.

Van Rensbergen, P., De Batist, M., Klerkx, J., Hus, R., Poort, J., Vanneste, M., Granin, N., Khlystov, O., Krinitsky, P., 2002. Sublacustrine mud volcanoes and methane seeps caused by dissociation of gas hydrates in Lake Baikal. Geology 30, 631-634.

von Rad, U., Rosch, H., Berner, U., Geyh, M., Marchig, V., Schulz, H., 1996. Authigenic carbonates derived from oxidized methane vented from the Makran accretionary prism off Pakistan. Mar. Geol. 136, 55-77.

Yun, J.W., Orange, D.L., Field, M.E., 1999. Subsurface gas offshore of northern California and its link to submarine geomorphology. Mar. Geol. 154, 357-368. 